\title{
LA DOCTRINA CONSTITUCIONAL SOBRE LAS PRERROGATIVAS PARLAMENTARIAS EN ESPAÑA
}

\author{
Francisco FERnÁNDEZ SEgAdo \\ Catedrático de Derecho Constitucional. UCM \\ fdezsegado@der.ucm.es
}

\begin{abstract}
RESUMEN
El siguiente articulo versa en torno a la doctrina constitucional sobre las prerrogativas parlamentarias en España. Su estudio se abordará desde un punto de vista bistórico y se analizarán la finalidad de las mismas, así como las consecuencias que se despliegan tratando, además, del aforamiento de los parlamentarios.

Palabras clave: prerrogativas parlamentarias, inviolabilidad parlamentaria, inmunidad parlamentaria.

\section{ABSTRACT}

The following article deals with the constitutional doctrine on parliamentary prerogatives in Spain. Their study will be approached from a historical perspective and the purpose thereof shall be analysed as well as the consequences that unfold, in addition to dealing with the jurisdiction of the members of Parliament.
\end{abstract}

Keywords: parliamentary prerogatives, parliamentary privilege, parliamentary immunity.

\section{ZUSAMMENFASSUNG}

Der folgende Aufsatz befasst sich mit der Verfassungslehre in Bezug auf die spezifischen Vorrechte der Parlamentarier in Spanien. Die Untersuchung geschiebt aus historischer Sicht und es wird der Zweck der Vorrechte, sowie die Folgen, die sich daraus ergeben, untersucht. Außerdem beschäftigt sich der Artikel mit der Gerichtsbarkeit gegenüber den Parlamentariern.

Schlüsselwörter: parlamentarische Vorrechte, Unanstastbarkeit der Parlamentarier, parlamentarische Immunität.

SUMARIO: I. LAS PRERROGATIVAS PARLAMENTARIAS EN UNA PERSPECTIVA HISTÓRICA.-II. FINALIDAD DE ESTAS PRERROGATIVAS Y CONSECUENCIAS QUE DE LA MISMA SE DERIVAN.-III. LA INVIOLABILIDAD PARLAMENTARIA.- - 1. Su caracterización y delimitación material y funcional.-2. Naturaleza jurídico-penal de esta prerrogativa.-3. La imposi- 
ble aplicación a la inviolabilidad de la técnica procesal de la inmunidad.-IV. LA INMUNIDAD PARLAMENTARIA.-1. Su caracterización como prerrogativa institucional.-2. Diseño de la prerrogativa y contenido de la misma.-3. Su ámbito material.-4. El momento de solicitud a la Cámara del suplicatorio.—5. El pronunciamiento parlamentario sobre el suplicatorio. Sus exigencias desde la perspectiva constitucional.-6. El control en sede constitucional del acto parlamentario denegatorio del suplicatorio.-V. EL AFORAMIENTO DE LOS PARLAMENTARIOS.-VI. REFLEXIÓN FINAL.

\section{LAS PRERROGATIVAS PARLAMENTARIAS EN UNA PERSPECTIVA HISTÓRICA}

1. Un amplio sector de la doctrina ha visto en el parlamentarismo medieval inglés los primeros antecedentes de las llamadas prerrogativas parlamentarias, y de modo particular de las dos más características: la inviolabilidad (freedom of speech) y la inmunidad (freedom from arrest or molestation), bien que no falten quienes consideran irrelevante la freedom from arrest como origen de la inmunidad parlamentaria ${ }^{1}$, por cuanto se trataría de una institución derivada de la curia medieval, generalizada en gran parte de Europa, y que nunca dejó de responder a su fundamento originario, esto es, a la exigencia de seguridad en un peligroso y, con frecuencia, largo viaje para acudir a las llamadas del rey a «Consejo». Por lo mismo, según esta doctrina, el origen de la moderna inmunidad parlamentaria habría que verlo en la Francia revolucionaria.

Por nuestra parte, no nos cabe duda de que ese origen ha de verse en el parlamentarismo inglés, en el que se considera ${ }^{2}$ que hacia el año 1450 los parliamentary privileges comenzaron a asumir una forma coherente en el paisaje constitucional al iniciar cada sesión parlamentaria el speaker de la Cámara de los Comunes con un discurso reclamando al monarca «the ancient rights and privileges of the Commons». El chief justice Edward Coke, en su obra Institutes of the Laws of England (1644), ya se hacía eco, analizándolos, de estos privilegios ${ }^{3}$.

${ }^{1}$ Tal es, por ejemplo, la posición de A. Fernández-Miranda y Campoamor, «Origen histórico de la inviolabilidad e inmunidad parlamentarias», Revista de la Facultad de Derecho de la Universidad Complutense, núm. 10 (monográfico), 1986, pp. 175 y ss., en concreto p. 199.

2 I. Loveland, Constitutional Law, Administrative Law and Human Rights (A Critical Introduction), 4. ${ }^{a}$ ed., Oxford-New York, Oxford University Press, 2006, p. 264.

3 Éstos eran los términos utilizados por Coke en su análisis de los parliamentary privileges: «Every court of justice hath rules and customs for its directions [...] It is lex et consuetudo parliamenti that all weighty matters in any Parliament moved concerning the peers of the 
El Strode's case $(1512)^{4}$ es un buen ejemplo de cómo ya en el siglo xvI estos privilegios eran algo más que puras reivindicaciones de los parlamentarios. Strode era un parlamentario que había promovido leyes para regular la industria de la estañadura. Sus actividades contrariaban a los Stannary Courts (Tribunales de las minas de estaño) de Cornwall y Devon. Esos tribunales iban a condenar a Strode por molestar y perturbar a los mineros locales del estaño, condenándolo a prisión. Este encarcelamiento desencadenó una rápida respuesta no sólo de los Comunes, sino del Parlamento en su conjunto. Una ley, conocida generalmente como la Strode's Act, fue rápidamente aprobada, condenando tanto la acción adoptada por la Stannary Court como advirtiendo a cualesquiera otros órganos frente a persecuciones de análoga naturaleza en el futuro.

El triunfo del Parlamento en su histórico conflicto con el rey en la Glorious Revolution condujo a la definitiva consagración de estas prerrogativas (de modo muy particular de la inviolabilidad), que con mayor rigor histórico podían ser calificadas en la época de verdaderos privilegios. El art. IX del Bill of Rights (1689) es la prueba fehaciente de ello. En él se disponía: «That the freedom from speech, and debates or proceedings in Parliament ought not to be impeached or questioned in any court or place out of Parliament». El principal efecto de esta disposición sería el de que ningún miembro del Parlamento podía ser hecho responsable por los tribunales por las expresiones pronunciadas en el curso de los procedimientos parlamentarios. De esta forma, los miembros de las Cámaras podían hablar en ellas sabiendo que eran inmunes frente a la «law of defamation» ${ }^{5}$.

En cuanto al privilegio de la freedom from arrest, protegía a los miembros del Parlamento frente a las detenciones con respecto a los procedimientos civiles durante el periodo, consuetudinariamente consagrado, que iba de los cuarenta días inmediatamente anteriores a los cuarenta días posteriores a aquel o aquellos en que tuviera lugar la sesión del Parlamento, pero no operaba con respecto a los procedimientos criminales. Al aplicarse tan sólo a la detención civil («civil arrest»), este privilegio tuvo escasa

realm, or commons in parliament assembled, ought to be determined, adjudged, and discussed by the course of the parliament, not by the civil law nor yet by the common laws of this realm used in more inferiour courts».

${ }^{4}$ Sobre el Strode's case, cfr. I. Loveland, Constitutional Law, Administrative Law..., op. cit., pp. 265-266.

5 A. W. Bradley y K. D. EwIng, Constitutional and Administrative Law, 13. ${ }^{a}$ ed., Essex (England), Pearson-Longman, 2003, p. 216. 
importancia en Inglaterra desde que se produjera la virtual abolición de la prisión por deudas ${ }^{6}$.

La Revolución Francesa incorporaría a su instrumental jurídico, desde sus primeros momentos, el instituto jurídico de la inviolabilidad, bien que concibiéndolo en forma tan amplia que no podría equipararse con el que ahora identificamos con tal nombre. Bien revelador sería el decreto de la Asamblea Nacional en que se había constituido el «Tercer Estado» de 20 de junio de 1789, norma que se abría prescribiendo que: «la Asamblea proclama que la persona de cada diputado es inviolable». Un Decreto de 26 de junio de 1790 perfeccionaría el sistema. La inviolabilidad reclamada por el Parlamento para sus miembros no perseguía en último término, como señalaría Barthélemy ${ }^{7}$, sino transferir a las Asambleas representativas del liberalismo una parte de los beneficios del viejo axioma absolutista: «the king can not do wrong». La propia terminología empleada por los revolucionarios parece apuntar en este mismo sentido.

El 22 de marzo de 1791 se delimitaba con cierta nitidez el instituto de la inmunidad, al precisarse que ésta no entrañaba una traslación de competencia jurisdiccional, sino la necesidad de la autorización de la Asamblea para procesar a uno de sus miembros. Y la Constitución de 3 de septiembre de 1791 terminará de delimitar con nitidez los dos institutos de la inviolabilidad e inmunidad. De ellos se ocuparán los arts. 7 y 8 de la Sección Quinta del Capítulo I del Título III. De acuerdo con el primero de ellos: «Les représentants de la Nation sont inviolables: ils ne pourront être recherchés, accusés ni jugés en aucun temps pour ce qu'ils auront dit, écrit ou fait dans l'exercice de leurs fonctions de représentants». Y el precepto siguiente delineará la inmunidad en los siguientes términos: «Ils (los representantes de la nación) pourront, pour faits criminels, être saisis en flagrant délit, ou en vertu d'un mandat d'arrêt; mais il en sera donné avis, sans délai, au Corps législatif; et la poursuite ne pourra être continuée qu'après que le Corps législatif aura décidé qu'il y a lieu à accusation».

2. En España, ya la Constitución de Cádiz de 1812 acogía el instituto de la inviolabilidad. El párrafo primero de su art. 128 disponía: «Los diputados serán inviolables por sus opiniones, y en ningún tiempo ni caso, ni por ninguna autoridad, podrán ser reconvenidos por ellas». Esta previsión se complementaba con la determinación de que durante las sesiones de Cortes y el mes inmediato posterior, los diputados no podían ser demanda-

\footnotetext{
${ }^{6}$ Ibid., p. 215.

7 J. BARThélemy y P. Duez, Traité de Droit Constitutionnel, Paris, Dalloz, 1933, p. 569.
} 
dos civilmente, ni ejecutados por deudas. Y en lo que se refiere a las causas criminales que se intentaren contra ellos, el propio precepto establecía un peculiar régimen de aforamiento, pues los diputados «no podrán ser juzgados sino por el Tribunal de Cortes en el modo y forma que se prescriba en el reglamento del gobierno interior de las mismas». Argüelles, en su célebre Discurso Preliminar, ya dejaba claro que la finalidad de la inviolabilidad de los diputados era inequívocamente funcional, no respondiendo la misma a ningún privilegio de carácter personal. «La absoluta libertad de las discusiones —escribe Argüelles- ${ }^{8}$ se ha asegurado con la inviolabilidad de los diputados por sus opiniones en el ejercicio de su cargo, y prohibiendo que el rey y sus ministros influyan con su presencia en las deliberaciones». En la misma dirección se había de pronunciar Salas, quien, tras afirmar que no es un privilegio que los diputados sean inviolables por sus opiniones, razonaba que lo que claramente quería decir el art. 128 era que los diputados no podían ser reconvenidos por lo que dijeran en las sesiones de las Cortes, «y esto es muy justo, porque en estas asambleas debe haber la mayor libertad, para que oyendo las opiniones de todos forme la Asamblea la suya con pleno conocimiento»?.

Sería la Constitución de 1837 la primera en diferenciar con nitidez los institutos de la inviolabilidad e inmunidad. El primero de ellos era recepcionado en el art. 41, que, concisa pero inequívocamente, disponía: «Los senadores y los diputados son inviolables por sus opiniones y votos en el ejercicio de su encargo». El precepto inmediato posterior acogía en términos bien actuales la prerrogativa de la inmunidad parlamentaria. A tenor del mismo: «Los senadores y los diputados no podrán ser procesados ni arrestados durante las sesiones sin permiso del respectivo cuerpo colegislador, a no ser hallados in fraganti; pero en este caso, y en el de ser procesados o arrestados cuando estuvieren cerradas las Cortes, se deberá dar cuenta lo más pronto posible al respectivo cuerpo para su conocimiento y resolución».

Las Constituciones subsiguientes, en sus mismos términos (como en el caso de la Constitución de 1845), con pequeñas modificaciones (como en el caso de la «nonnata» de 1856) o con innovaciones mayores encaminadas a una mayor garantía (como sería el caso de las Constituciones de 1869, 1876 y, sobre todo, 1931), recogieron los institutos que nos ocupan.

\footnotetext{
8 A. de ArgüELles, Discurso preliminar a la Constitución de 1812, Madrid, Centro de Estudios Constitucionales, 1981, p. 87.

9 R. Salas, Lecciones de Derecho Público Constitucional, Madrid, Centro de Estudios Constitucionales, 1982, pp. 204-205.
} 
En definitiva, todo el constitucionalismo histórico español ha sido receptivo a las prerrogativas parlamentarias, aunque la Constitución de Cádiz de 1812, la más circunspecta de todas, se limitara a contemplar la prerrogativa de la inviolabilidad.

En cuanto a la doctrina preconstitucional que se ha hecho eco de ellas, se ha mostrado plenamente acorde con esa perspectiva funcional a la que aludía Argüelles. Buen ejemplo de ello lo encontramos en Pérez Serrano, quien veía la esencia de los que denominaba «privilegios parlamentarios» en que constituían garantías llamadas a asegurar el normal desenvolvimiento y la libre actuación de las Cámaras, tratándose de una normación especial impuesta por la naturaleza de la institución y necesaria para que ésta pueda cumplir sus fines. El mencionado autor diferenciaba los privilegios de carácter colectivo, que pertenecen a la Asamblea como cuerpo (así, la autonomía parlamentaria), de los privilegios individuales, que, aunque correspondiendo en principio a la Cámara y estando concebidos en beneficio de la misma, redundaban en favor de los parlamentarios, aunque no debían entrañar una ventaja personal, sino una protección objetiva, ubicándose aquí las prerrogativas parlamentarias ${ }^{10}$.

3. La Constitución de 1978 contempla las prerrogativas parlamentarias en su art. 71, ubicado en el Capítulo I («De las Cámaras») del Título III («De las Cortes Generales»), norma que iba a sufrir muy pocas variaciones a lo largo del «iter» constituyente. En lo que a sus tres primeros apartados se refiere, que son los que ahora interesan, en realidad, la única modificación digna de ser resaltada es la supresión de la inicialmente prevista inviolabilidad no sólo respecto de las «opiniones manifestadas en el ejercicio de sus funciones», sino también respecto de «los actos realizados» por los parlamentarios al hilo de ellas. Esta previsión sufrió diversas vicisitudes a lo largo del proceso constituyente. En la Comisión Constitucional del Congreso de los Diputados, el art. 66.1 (equivalente al actual art. 71.1) quedó redactado en los siguientes términos: «Los diputados y senadores gozan de inviolabilidad por las opiniones manifestadas en el ejercicio de sus funciones. Asimismo, gozan de inviolabilidad los actos efectuados en el ejercicio de sus funciones, de acuerdo con lo que disponga una ley orgánica». Con algún pequeño cambio en su redacción, este precepto continuó hasta su llegada a la Comisión Mixta Congreso-Senado, que suprimió su inciso segundo.

A tenor, pues, de los tres primeros apartados del art. 71:

10 N. Pérez Serrano, Tratado de Derecho Político, Madrid, Civitas, 1976, p. 771. 
«1. Los diputados y senadores gozarán de inviolabilidad por las opiniones manifestadas en el ejercicio de sus funciones.

2. Durante el periodo de su mandato los diputados y senadores gozarán asimismo de inmunidad y sólo podrán ser detenidos en caso de flagrante delito. No podrán ser inculpados ni procesados sin la previa autorizaxión de la Cámara respectiva.

3. En las causas contra diputados y senadores será competente la Sala de lo Penal del Tribunal Supremo» ${ }^{11}$.

Esta norma no ha sido objeto de un específico desarrollo legislativo, no obstante los varios llamamientos que el Tribunal Constitucional ha tenido ocasión de hacer al poder legislativo, señalando, por ejemplo, que la regulación legal de la prerrogativa de aforamiento de diputados y senadores se encuentra en un confuso marco normativo ${ }^{12}$, que viene delimitado por una ley preconstitucional de casi un siglo de vida, la Ley de 9 de febrero de 1912, declarando los Tribunales que han de entender en el conocimiento de las causas contra senadores y diputados, al margen ya de algunas otras disposiciones de la Ley de Enjuiciamiento Criminal y de los Reglamentos de cada una de las Cámaras.

La ausencia de una legislación de desarrollo ha hecho aún más necesaria la tarea de clarificación llevada a cabo por el Tribunal Constitucional, que ha dedicado a la materia un buen número de decisiones a las que resulta inexcusable atender si se quiere comprender cómo operan realmente estas prerrogativas. Añadamos que el Tribunal ha efectuado unas aportaciones muy notables con vistas a la racionalización de unas instituciones que, como bien se ha dicho ${ }^{13}$, por su anacronismo e historia encajan difícilmente en los principios propugnados por nuestra Constitución.

\footnotetext{
${ }^{11}$ El precepto se cierra con un cuarto apartado del siguiente tenor: «Los diputados y senadores percibirán una asignación que será fijada por las respectivas Cámaras».

12 Sentencia del Tribunal Constitucional (en adelante STC) 22/1997, de 11 de febrero, fundamento jurídico (en adelante FJ) $4 .^{\circ}$

${ }^{13} \mathrm{~J}$. M. ${ }^{a}$ Morales Arroyo, «Las prerrogativas parlamentarias a la luz de la jurisprudencia constitucional (a propósito de las Sentencias del Tribunal Constitucional 51/1985, de 10 de abril, y 90/1985, de 22 de julio)», Revista de las Cortes Generales, núm. 12, tercer cuatrimestre de 1987, pp. 189 y ss., en concreto p. 217.
} 


\section{FINALIDAD DE ESTAS PRERROGATIVAS Y CONSECUENCIAS QUE DE LA MISMA SE DERIVAN}

1. En el marco de un Estado que se define como social y democrático de Derecho, y en cuanto Estado de Derecho que debe asegurar el imperio de la ley, quedando todos, ciudadanos y poderes públicos, sujetos a la misma y, más ampliamente aún, al ordenamiento jurídico en su conjunto, un Estado, además, que propugna como valores superiores de su ordenamiento jurídico, entre otros, la justicia y la igualdad, y en el que, asimismo, los derechos fundamentales no sólo se nos presentan como derechos subjetivos, sino también como «elementos esenciales de un ordenamiento objetivo de la comunidad nacional, en cuanto ésta se configura como marco de una convivencia humana, justa y pacífica» ${ }^{14}$, y en cuanto tales derechos desempeñan por ello mismo un rol nuclear en nuestro sistema jurídico, ocupando un lugar privilegiado en la Constitución, en íntima conexión con el orden axiológico constitucional, esos mismos derechos exigen una interpretación tout court acorde con el principio del favor libertatis, o lo que es igual, una interpretación maximalista, tal y como ha reiterado cientos de veces el Tribunal Constitucional ${ }^{15}$. Resulta una evidencia obvia, que en este Estado no tienen cabida los privilegios, y menos aún pueden tenerla cuando, como acontece en el caso de las prerrogativas parlamentarias, inciden negativamente en el ámbito del derecho a la tutela judicial efectiva, como ha reconocido con reiteración el «intérprete supremo de la Constitución» ${ }^{16}$. La inviolabilidad, porque impide la apertura de cualquier clase de proceso o procedimiento que tenga por objeto exigir responsabilidad a los diputados o senadores por las opiniones manifestadas en el ejercicio de sus funciones. La inmunidad, porque somete determinados procesos al requisito de la autorización de la Cámara legislativa respectiva, actuando así como presupuesto de procedibilidad determinante, caso de ser denegada la autorización, del cierre del proceso con su consiguiente archivo.

${ }^{14}$ STC 25/1981, de 14 de julio, FJ 5. ${ }^{\circ}$

15 Así, por poner un ejemplo, en la STC 66/1985, de 23 de mayo, el Tribunal (en el FJ 2. ${ }^{\circ}$ ) afirmaba: «El lugar privilegiado que en la economía general de nuestra Constitución ocupan los derechos fundamentales y libertades públicas que en ella se consagran está fuera de toda duda. De ello resulta no sólo la inconstitucionalidad de todos aquellos actos del poder, cualquiera que sea su naturaleza y rango, que los lesionen, sino también la necesidad, tantas veces proclamada por este Tribunal, de interpretar la Ley en la forma más favorable a la maximalización de su contenido».

${ }^{16}$ Entre otras, en la STC 243/1988, de 19 de diciembre, FJ 3. ${ }^{\circ}$, A). 
Quiere todo ello decir, que la inviolabilidad e inmunidad parlamentarias, al igual que el aforamiento, en modo alguno pueden ser visualizadas como en tiempos pretéritos en el sentido de privilegios personales de los parlamentarios. El Tribunal Constitucional, en cada ocasión que ha debido enfrentarse con estas prerrogativas, ha insistido en esta idea. Así, la Sentencia 22/1997 sostenía que «las prerrogativas parlamentarias no se confunden con el privilegio (aunque es cierto que, en ocasiones, ha empleado el término "privilegios" para identificar estas prerrogativas, bien que, por lo general, matizando que no se trata de lo que entendemos realmente por ese vocablo) ni tampoco pueden considerarse como expresión de un pretendido ius singulare, pues en ellas no encontramos las notas de la desigualdad y la excepcionalidad» ${ }^{17}$. Antes al contrario, añadirá el juez de las leyes, ofrecen un tratamiento jurídico diferenciado a situaciones subjetivas cualitativa y funcionalmente diferenciadas por la propia Constitución, resultando, por tanto, de obligada aplicación siempre que concurra el presupuesto de hecho por ellas contemplado.

Estas reflexiones dejan ya muy clara cuál es la auténtica razón de ser de estas prerrogativas. Decir que se trata de prerrogativas funcionales no es ninguna novedad en España, pues hace ya casi dos siglos que Argüelles, como antes vimos, tuvo oportunidad de decir lo mismo. Sin embargo, las consecuencias que de ello ha extraído el Tribunal Constitucional sí que pueden considerarse novedosas. $\mathrm{Y}$ en ellas nos centramos a continuación.

2. A título previo conviene recordar la doctrina constante del Tribunal ${ }^{18}$ en relación a las prerrogativas de los miembros de las Cortes Generales. La razón de ser de estas garantías debe situarse en la necesidad de «proteger de forma cualificada la libertad, autonomía e independencia de los órganos constitucionales, interés superior del ordenamiento de todo Estado democrático de Derecho (art. 1.1 CE) e instrumento imprescindible para garantizar la efectiva separación entre los distintos poderes del Estado». «Esta protección jurídica cualificada se articula constitucionalmente [...] mediante el tratamiento de situaciones subjetivas no parangonables con las ordinarias, puesto que se atribuyen a los miembros de las Cortes Generales no en atención a un interés privado de sus titulares, sino a causa de un interés general, cual es el de asegurar su libertad e independencia en tanto que reflejo de la que se garantiza al órgano constitucional al que pertenecen» ${ }^{19}$.

\footnotetext{
${ }_{17}$ STC 22/1997, de 11 de febrero, FJ 5. ${ }^{\circ}$

18 Así lo constata el propio Tribunal Constitucional en su Auto (en adelante ATC) 236/2000, de 9 de octubre, FJ $1 .^{\circ}$

19 STC 22/1997, de 11 de febrero, FJ 5.
} 
A partir de estas premisas, y convergiendo en la finalidad común que se acaba de señalar, las tres prerrogativas que contemplan los tres primeros apartados del art. $71 \mathrm{CE}$, con rasgos propios cada una de ellas, se orientan hacia unos peculiares objetivos: a) proteger a los legítimos representantes del pueblo de acciones penales con las que se pretenda coartar su libertad de opinión (inviolabilidad); b) impedir indebida y fraudulentamente su participación en la formación de la voluntad de la Cámara, poniéndolos al abrigo de querellas insidiosas o políticas que, entre otras hipótesis, confunden, a través de la utilización inadecuada de los procesos judiciales, los planos de la responsabilidad política y la penal —cuya delimitación considera el Tribunal que es uno de los mayores logros del Estado constitucional como forma de organización libre y plural de la vida colectiva- (inmunidad), y c) proteger la independencia del órgano y el ejercicio de las funciones del cargo constitucionalmente relevantes (aforamiento $)^{20}$. El Tribunal sienta una doctrina plenamente convergente con la fijada por otros Tribunales análogos europeos. Así, por poner un ejemplo, en su Sentencia núm. 81, del año 1975 (decidida en el Palazzo della Consulta el 21 de marzo de 1975), la Corte Costituzionale justificaba las excepcionales derogaciones a la actuación de la función jurisdiccional que entrañan estas prerrogativas en base a que las mismas se consideran necesarias para la «salvaguardia dell'esercizio delle funzioni sovrane spettanti al Parlamento» ${ }^{21}$.

Ese carácter objetivo que caracteriza a estas garantías se refuerza aún más en el caso de la inmunidad, de tal modo que el Tribunal ha considerado que esta prerrogativa adquiere el sentido de una «prerrogativa institucional»22. Y ello por cuanto la inmunidad en modo alguno está concebida como una protección de los diputados y senadores frente a la improcedencia o falta de fundamentación de las acciones penales, bien al contrario, se contempla frente a «la eventualidad de que la vía penal sea utilizada con la intención de perturbar el funcionamiento de las Cámaras o de alterar la composición que a las mismas ha dado la voluntad popular» ${ }^{23}$. De esta caracterización esencialmente objetiva y funcional, institucional, en definitiva, de las prerrogativas, el Tribunal ha extraído, como antes decíamos, una serie de consecuencias, a las que pasamos a referirnos.

\footnotetext{
${ }^{20}$ STC 22/1997, de 11 de febrero, FJ 6. ${ }^{\circ}$, ab initio.

${ }^{21}$ Corte Costituzionale, Sentencia núm. 81 , de 1975, considerato in diritto $3 .^{\circ}$

22 SSTC 206/1992, de 27 de noviembre, FJ 3. ${ }^{\circ}$, y 123/2001, de 4 de junio, FJ $4 .^{\circ}$

23 SSTC 90/1985, de 22 de julio, FJ 6. ${ }^{\circ}$, y 206/1992, de 27 de noviembre, FJ 4. ${ }^{\circ}$
} 
A) En cuanto la sustracción al Derecho común que estas garantías entrañan está estrechamente conectada al ejercicio de una función ${ }^{24}$, es evidente que la garantía no puede concebirse como un derecho personal (ius singulare), sino como un derecho reflejo de que goza el parlamentario en su condición de miembro de la Cámara legislativa ${ }^{25}$. En esta misma dirección, el «intérprete supremo de la Constitución» ha vinculado estas prerrogativas con el derecho fundamental de acceder en condiciones de igualdad a los cargos públicos que acoge el art. 23.2 CE. Es tal derecho un derecho de configuración legal, como inequívocamente se dice en ese precepto, y esa configuración comprende los Reglamentos parlamentarios a los que compete regular y ordenar los derechos y atribuciones que los parlamentarios ostentan; de tal suerte que, como entiende el Tribunal ${ }^{26}$, una vez conferidos dichos derechos por la norma reglamentaria pasan a formar parte del status propio del cargo de parlamentario, pudiendo ser defendidas ante el propio Tribunal sus pretendidas transgresiones, en cuanto contenido del ius in officium. Aún con mayor nitidez, el juez de las leyes ha podido decir ${ }^{27}$, que las prerrogativas de la inmunidad e inviolabilidad se incorporan y encuentran su acomodo natural en el contenido del derecho fundamental reconocido en el art. 23.2 CE, que, como de algún modo ya se ha dicho, garantiza no sólo el acceso o permanencia en el cargo representativo, sino también los derechos y prerrogativas propios del status del cargo.

B) Como garantías jurídicamente vinculadas a la satisfacción de un interés institucional y permanente del ordenamiento, las prerrogativas parlamentarias son ius cogens y, por tanto, indisponibles por sus titulares ${ }^{28}$. Son asimismo imprescriptibles e irrenunciables ${ }^{29}$. Su irrenunciabilidad significa, como es patente por lo demás, que estas prerrogativas no son disponibles por los parlamentarios, de manera que una eventual renuncia a las mismas carecería de toda eficacia jurídica, pues es evidente que en cuanto se integran como parte del ius in officium, vinculándose de modo inextricable con las funciones públicas que desarrollan en cuanto miembros de las Cámaras, quedan al margen de la esfera de libre disposición personal del parlamentario. En la misma dirección, hace ya más de tres cuartos de siglo,

${ }^{24}$ STC 51/1985, de 10 de abril, FJ $6{ }^{\circ}$

25 STC 243/1988, de 19 de diciembre, FJ 3. ${ }^{\circ}$, A).

26 STC 205/1990, de 13 de diciembre, FJ 5. ${ }^{\circ}$

27 SSTC 22/1997, de 11 de febrero, FJ 2. ${ }^{\circ}$, y 123/2001, de 4 de junio, FJ 3. ${ }^{\circ}$

28 STC 22/1997, de 11 de febrero, FJ 5. ${ }^{\circ}$, in fine.

${ }^{29}$ ATC 236/2000, de 9 de octubre, FJ 1 . $^{\circ}$ 
Barthélemy y Duez escribían: «Elles ne sont pas donnés aux parlementaires dans leur propre intérêt, mais dans l'intérêt du libre exercise de la fonction: ils ne peuvent donc y renoncer» ${ }^{30}$. Y entre nosotros, Abellán, refiriéndose a la inmunidad, significa que el diálogo sobre la garantía se produce exclusivamente entre el órgano juzgador y la Cámara, y el interés de hacer valer la prerrogativa se concede a ésta y no al parlamentario ${ }^{31}$.

C) En cuanto que, como ya hemos puesto de relieve, la inviolabilidad y la inmunidad pueden incidir negativamente en el ámbito del derecho a la tutela judicial efectiva de terceros, resulta patente que tales garantías sólo son susceptibles de una interpretación estricta y vinculada a los supuestos expresamente contemplados en la Constitución. «Las prerrogativas parlamentarias - sostuvo el Tribunal en una de sus primeras decisiones sobre la materia- ${ }^{32}$ han de ser interpretadas estrictamente para no devenir privilegios que puedan lesionar derechos fundamentales de terceros». En sintonía con tal interpretación estricta, el Tribunal ha rechazado la introducción de la vía analógica como criterio hermenéutico en relación con estos institutos ${ }^{33}$. De igual forma, no es constitucionalmente legítima una extensión legislativa de los mismos, interpretación que, tras una cuestión de inconstitucionalidad interna, esto es, planteada ante el Pleno del Constitucional por una de sus Salas (en la STC 243/1988), condujo al Tribunal a declarar la inconstitucionalidad de la reforma introducida en la Ley Orgánica 1/1982, de 5 de mayo, sobre protección del derecho al honor, a la intimidad personal y familiar y a la propia imagen, por la Ley Orgánica 3/1985, de 29 de mayo, de conformidad con la cual se ampliaba el ámbito del art. $71 \mathrm{CE}$, introduciendo una autorización previa en el marco de procesos civiles iniciados contra diputados y senadores de resultas de las opiniones manifestadas en el ejercicio de sus funciones, autorización que, según el Tribunal, dicho precepto constitucional sólo consiente en los procesos penales ${ }^{34}$.

En análoga dirección, el juez de las leyes declaró la inconstitucionalidad de algunos preceptos de la Ley de la Comunidad Vasca 2/1981, de 12 de febrero, sobre reconocimiento de derechos de inviolabilidad e inmunidad de los miembros del Parlamento Vasco, con base en que, siendo los

30 J. Barthélemy y P. Duez, Traité de Droit Constitutionnel, op. cit., p. 565.

31 Á. M. Abellán, El estatuto de los parlamentarios y los derechos fundamentales, Madrid, Tecnos, 1992, p. 79.

32 STC 51/1985, de 10 de abril, FJ 6. ${ }^{\circ}$

33 STC 9/1990, de 18 de enero, FJ 4. ${ }^{\circ}$, in fine.

34 STC 9/1990, de 18 de enero, FJ 5. ${ }^{\circ}$ 
Estatutos de Autonomía, ante el silencio de la Constitución, el lugar adecuado para regular el estatus de los parlamentarios en cuanto se refiere a su inviolabilidad e inmunidad, y limitándose el Estatuto de Autonomía del País Vasco a garantizar exclusivamente, en relación con el estatus de los parlamentarios vascos, que «no podrán ser detenidos ni retenidos, sino en caso de flagrante delito», lo que suponía el reconocimiento de una inmunidad parcial o limitada en relación con los actos delictivos cometidos por aquéllos, la Ley 2/1981 ampliaba esa prerrogativa convirtiéndola en una inmunidad plena o completa, ya que, según su art. 2.1, los miembros del Parlamento Vasco «no podrán ser inculpados ni procesados sin la previa autorización del Parlamento Vasco». Desde una perspectiva formal, el Tribunal Constitucional consideraría inconstitucional tal ampliación de la inmunidad parlamentaria por una ley de la Comunidad Autónoma Vasca, con base en que ello suponía la modificación del Estatuto de Autonomía por un cauce distinto del previsto tanto en la Constitución como en el propio Estatuto ${ }^{35}$, pero no albergamos la más mínima duda de que, en el fondo, la declaración de inconstitucionalidad de esta ampliación de la prerrogativa de inmunidad de los parlamentarios vascos era asimismo deudora de ese principio de ilegitimidad constitucional de la extensión por la vía legislativa de estas prerrogativas ${ }^{36}$.

En fin, también es reconducible a la visión estricta de estas prerrogativas el rechazo del Tribunal a que la inmunidad pueda operar, de facto, como una extensión de los límites de la prerrogativa, en parte vecina, de la inviolabilidad ${ }^{37}$.

Esa misma interpretación estricta, en atención al interés que preserva, debe seguirse en relación a la prerrogativa de aforamiento, de modo tal que cuando se constate por la Sala Segunda del Tribunal Supremo la pérdida sobrevenida de la condición de parlamentario, la devolución de la causa al Juzgado de Instrucción no supondrá vulneración alguna del derecho fundamental a la tutela judicial efectiva (art. 24.1 CE) y al juez predeterminado por la ley (art. 24.2 CE), toda vez que la cognición del Tribunal Supremo en este tipo de procesos sólo se justifica constitucionalmente por razón de la prerrogativa de aforamiento (art. $71.3 \mathrm{CE}$ ) y en atención a la

35 STC 36/1981, de 12 de noviembre, FJ $4 .^{\circ}$

${ }^{36}$ En el ATC 86/1982, de 9 de febrero, FJ único, el Tribunal recordaba que en su Sentencia de 12 de noviembre de 1981 había declarado «inaplicables a los miembros de los Parlamentos de las Comunidades Autónomas los preceptos del art. 71 de la Constitución, exclusivamente referidos a los de las Cortes Generales».

37 Así lo señaló el Tribunal en su STC 206/1992, de 27 de noviembre, FJ 3. 
función institucional que le es propia, y no cuando ésta queda privada de su razón de ser por haber perdido el encausado su condición de miembro de las Cortes Generales ${ }^{38}$.

En definitiva, a juicio del «intérprete supremo de la Constitución» ${ }^{39}$, las prerrogativas parlamentarias han de ser interpretadas estrictamente a partir de una comprensión del sentido de la prerrogativa misma y de los fines que ésta procura, esto es, tanto en el sentido lógico de sujeción a los límites objetivos que le impone la Constitución, como en el teleológico de razonable proporcionalidad al fin que responden.

3. Antes de entrar en el análisis de las dos primeras prerrogativas, la inviolabilidad y la inmunidad, quizá convenga recordar que el Tribunal ha considerado que, aunque tienen distinto contenido y finalidad específica, encuentran su fundamento en el objetivo común, al que nos refiriéramos, de garantizar la libertad e independencia de la institución parlamentaria, y en tal sentido son complementarias ${ }^{40}$. Bien es verdad que tras esa reflexión, en la propia decisión (aunque ya lo había hecho en otras anteriores) matiza que la existencia de un objetivo común no impide que sean instituciones distintas con características propias.

\section{LA INVIOLABILIDAD PARLAMENTARIA}

\section{Su caracterización y delimitación material y funcional}

1. La inviolabilidad ha sido caracterizada ${ }^{41}$ como «un privilegio» (expresión ciertamente no muy afortunada) ${ }^{42}$ de naturaleza sustantiva que garantiza la irresponsabilidad jurídica de los parlamentarios por las opiniones manifestadas en el ejercicio de sus funciones, entendiendo por tales aquellas que realicen en actos parlamentarios y en el seno de cualquiera de

${ }^{38}$ STC 22/1997, de 11 de febrero, FJ $8 .^{\circ}$

39 STC 123/2001, de 4 de junio, FJ $4 .^{\circ}$, in fine.

40 STC 9/1990, de 18 de enero, FJ 3.०, A).

${ }^{41}$ STC 243/1988, de 19 de diciembre, FJ 3. ${ }^{\circ}$, B).

${ }^{42}$ Con mucho mayor acierto, en una decisión justamente de la misma fecha que la STC 243/1988, el Tribunal caracterizaría la inviolabilidad como «un derecho reflejo del que el parlamentario goza como miembro de la institución» [ATC 1326/1988, de 19 de diciembre, FJ 2. ${ }^{\circ}$, b)]. Bien es verdad que también en la STC 243/1988 el Tribunal matiza que estos «privilegios» se confieren «no como derechos personales, sino como derechos reflejos de los que goza el parlamentario en su condición de miembro de la Cámara legislativa» [STC 243/1988, de 19 de diciembre, FJ 3. ${ }^{\circ}$, A)]. 
las articulaciones de las Cortes Generales o, por excepción, «en actos exteriores a la vida de las Cámaras que sean reproducción literal de un acto parlamentario», siendo finalidad específica del «privilegio» asegurar, a través de la libertad de expresión de los parlamentarios, la libre formación de la voluntad del órgano legislativo al que pertenezcan.

El contenido de esta prerrogativa parlamentaria ha sido configurado por el Tribunal, como acabamos de ver, como una garantía de naturaleza sustantiva que, en cuanto excluye la responsabilidad jurídica de los parlamentarios por las opiniones manifestadas en el ejercicio de su función parlamentaria, no requiere la interposición de una autorización previa. Innecesario es reiterar que no estamos ante un derecho personal, sino ante una garantía que se vincula con el ius in officium.

Es claro, como aduce el Tribunal ${ }^{43}$, que la inviolabilidad parlamentaria se orienta a la preservación de un ámbito cualificado de libertad en la crítica y en la decisión sin el cual el ejercicio de las funciones parlamentarias podría resultar mediatizado y frustrado, por ello, el proceso de libre formación de voluntad del órgano, y también es evidente que tal ámbito de libertad garantizado por la prerrogativa que examinamos no viene constreñido por el deber de prestar juramento o promesa de acatamiento a la Constitución que sobre los parlamentarios recae ${ }^{44}$.

Como fácilmente se puede percibir a la vista de la finalidad perseguida por esta prerrogativa, la principal problemática que la misma plantea es la de hasta dónde alcanza el ejercicio de las funciones de un parlamentario: ¿se ha de circunscribir a la actividad oficial? o, por el contrario, ¿puede el diputado o senador ejercer la función que le corresponde por cualquier cauce abierto a los demás ciudadanos, sin perder por ello su función el

${ }^{43}$ STC 51/1985, de 10 de abril, FJ 6. ${ }^{\circ}$

${ }^{44}$ En esta misma dirección, en su Sentencia 122/1983, el Tribunal señalaba que el deber de jurar o prometer el acatamiento a la Constitución y a un Estatuto de Autonomía (en este caso, al Estatuto de Galicia) que recaía sobre los miembros del Parlamento de Galicia podía entenderse como el compromiso de aceptar las reglas del juego político y el orden jurídico existente en tanto existe y a no intentar su transformación por medios ilegales. Pero «la fidelidad, en esta línea interpretativa, no entraña una prohibición de representar y de perseguir ideales políticos diversos de los encarnados en la Constitución y el Estatuto, siempre que se respeten aquellas reglas de juego, y no supone, por tanto, una renuncia a las libertades individuales consagradas por la Constitución, ni a la libre crítica del ordenamiento jurídico existente, ni de los actos políticos que se realicen». «Conviene recordar —añadía a continuación el Tribunal - que esa libertad de expresión está protegida por la prerrogativa de la inviolabilidad por los votos y opiniones que los miembros del Parlamento emitan en el ejercicio de su cargo [...], libertad que obviamente no viene coartada por la prestación del juramento o promesa debatido» (STC 122/1983, de 16 de diciembre, FJ 5. ${ }^{\circ}$ ). 
carácter que le corresponda, por razón de la materia y objeto de la actividad, continuando, por ende, cubierto por la inviolabilidad?

2. Se impone, pues, una delimitación material y funcional de la inviolabilidad parlamentaria. Respecto de la primera, parece evidente que la garantía no ampara cualesquiera actuaciones de los parlamentarios y sí sólo sus declaraciones de juicio o de voluntad (sus «opiniones», en la dicción literal del art. $71.1 \mathrm{CE})^{45}$. No deja de ser un dato significativo al respecto el hecho, ya mencionado, de la supresión en el texto del precepto equivalente, por la Comisión Mixta Congreso-Senado, de la dicción de que los diputados y senadores gozarían asimismo de inviolabilidad «por los actos realizados en el ejercicio de sus funciones, de acuerdo con lo que disponga una ley orgánica» (tal era la redacción del equivalente art. 70.1 tras su paso por la Comisión Constitucional del Senado).

La doctrina española, proclive de modo casi unánime a la más estricta comprensión de la prerrogativa, en perfecta sintonía con la posición asimismo dominante entre la literatura jurídica foránea, se ha mostrado partidaria de delimitar esas declaraciones de juicio o de voluntad cubiertas por la garantía de la inviolabilidad, al considerar ${ }^{46}$ que la actuación del parlamentario en el ejercicio regular de sus funciones, para la formación de la voluntad de la Cámara, debe inscribirse en el procedimiento constitucional y reglamentariamente establecido. Ello entraña que aunque nuestra Constitución, a diferencia de otros códigos políticos (como el alemán o el griego), no establece expresamente ninguna limitación, es evidente que la inviolabilidad está sujeta a límites. En ella, por ejemplo, no pueden encontrar amparo ni las calumnias, ni las injurias, ni conceptos ofensivos contra personas o instituciones, ni la apología para la comisión de delitos, pues tales manifestaciones mal pueden contribuir al ejercicio de las funciones parlamentarias ${ }^{47}$.

Más problemática se presenta la concreción funcional del ámbito de esta prerrogativa, que puede presentar, de principio, algunas dudas y, en especial, la relativa a si la inviolabilidad cubre toda la actuación de «relevancia política» del parlamentario o si, más estrictamente, la protección

${ }^{45}$ STC 51/1985, de 10 de abril, FJ 6. ${ }^{\circ}$

46 Á. Figueruelo Burrieza, «El grado de suficiencia en la motivación del suplicatorio y la doctrina del Tribunal Constitucional (comentario a la Sentencia 206/1992, de 27 de noviembre)», Revista de las Cortes Generales, núm. 27, tercer cuatrimestre de 1992, pp. 33 y ss., en concreto pp. 41-42.

${ }_{47}$ Idéntica es la posición de Á. M. Abellán, El estatuto de los parlamentarios..., op. cit., p. 42. 
dispensada por esta garantía no alcanza sino a la conducta de su titular en tanto que miembro del órgano colegiado, cesando, por tanto, cuando el sujeto despliegue ya su conducta - incluso con trascendencia política- al margen de las funciones parlamentarias.

A fin de intentar delimitar funcionalmente el ámbito que cubre este instituto, el juez de las leyes ha acudido, en primer término, a una interpretación literal y sistemática del ordenamiento constitucional, pero también de algunas disposiciones de los Reglamentos de las Cámaras, y más tarde, a una interpretación finalista o teleológica ${ }^{48}$. Y de resultas de todo ello ha hecho valer, en sintonía con la doctrina, la comprensión más estricta de la prerrogativa.

Aduce el Tribunal que el nexo entre inviolabilidad y ejercicio de funciones propias a la condición de parlamentario se halla claramente expuesto por el propio art. 71.1 CE. A no ser que la expresión «funciones» que recoge esta norma se entendiera en un sentido inespecífico (de corte sociológico y no jurídico), las mismas debieran identificarse en las que son propias del diputado o senador en tanto que sujetos portadores del órgano parlamentario, cuya autonomía, en definitiva, es la protegida a través de esta garantía individual. En consecuencia, «el diputado o senador ejercitaría [...] sus funciones sólo en la medida en que participase en actos parlamentarios y en el seno de cualesquiera de las articulaciones orgánicas de las Cortes Generales». Que esto es así lo confirman los Reglamentos de las Cámaras, y específicamente el Reglamento del Senado ${ }^{49}$, cuyo art. 21 señala que la inviolabilidad garantizará sólo «las opiniones manifestadas en actos parlamentarios» y los «votos emitidos en el ejercicio de su cargo».

Como confirmación constitucional de esta interpretación, el Tribunal atiende a lo dispuesto por el art. 67.3 de la Norma fundamental, de acuerdo con el cual «las reuniones de parlamentarios que se celebren sin convocatoria reglamentaria no vincularán a las Cámaras y no podrán ejercer sus funciones ni ostentar sus privilegios». Aunque el Tribunal reconoce que este precepto no se limita a contemplar la prerrogativa de la inviolabilidad, refiriéndose también, por ejemplo, a la protección penal de las asambleas y a la inmunidad de la sede parlamentaria, considera asimismo patente que

${ }^{48}$ STC 51/1985, de 10 de abril, FJ 6. ${ }^{\circ}$

49 El Reglamento del Congreso de los Diputados, en su art. 10, se limita, por lo que atañe a lo que venimos tratando, a reiterar la fórmula constitucional, aunque añade una precisión importante. A tenor del citado precepto: «Los diputados gozarán de inviolabilidad, aun después de haber cesado en su mandato, por las opiniones manifestadas en el ejercicio de sus funciones». 
su sentido es el de «vincular el reconocimiento de lo que llama "privilegios" parlamentarios al funcionamiento regular de las asambleas y de sus órganos», tesis que se ve reforzada por el hecho de que la inviolabilidad por las opiniones vertidas se vea necesariamente contrapesada por la sujeción a la disciplina parlamentaria.

Desde un análisis finalista de la garantía, la interpretación no podía ser muy distinta. A juicio del Tribunal, tal entendimiento estricto debe hacerse a partir de una comprensión del sentido de la prerrogativa misma y de los fines que ésta procura. Desde este enfoque, en cuanto las prerrogativas parlamentarias son, como ya se dijo, «sustracciones al Derecho común conectadas a una función», sólo en tanto esta función se ejerza pueden considerarse vigentes.

El interés a cuyo servicio se encuentra establecida la inviolabilidad es el de la protección de la libre discusión y decisión parlamentarias, doctrina en la que el Tribunal español sigue lo ya expuesto por la Corte Costituzionale diez años antes (en la Sentencia núm. 81, de 1975), decayendo tal protección cuando los actos hayan sido realizados por su autor en calidad de ciudadano (de «político» incluso), fuera del ejercicio de competencias y funciones que le pudieran corresponder como parlamentario. La conclusión es patente: «Las funciones relevantes para el art. 71.1 de la Constitución no son indiferenciadamente todas las realizadas por quien sea parlamentario, sino aquéllas imputables a quien, siéndolo, actúa jurídicamente como tal».

Ese entendimiento estricto, a juicio del Tribunal, no impide, sin embargo, las necesarias matizaciones, reconociendo que la «prerrogativa puede amparar también los actos "exteriores" a la vida de las Cámaras, que no sean sino reproducción literal de un acto parlamentario».

La interpretación expuesta no debe en modo alguno conducir a entender, como hacía el demandante en el proceso constitucional cerrado por la Sentencia 51/1985, que la reglamentación de las Cámaras pone límites a la actividad pública de los parlamentarios, pues tal normación se circunscribe a precisar cuáles de sus actividades constituyen funciones, pudiendo al margen de ellas, como resulta obvio, formular los parlamentarios las críticas a la acción del gobierno que tengan por conveniente, como cualquier ciudadano, pero sin gozar de la protección del art. $71.1 \mathrm{CE}$, sino sólo de la genérica libertad de expresión que reconoce el art. 20 de la propia Norma suprema.

3. La prerrogativa de la inviolabilidad no sólo comporta la exención de cualquier responsabilidad, sino que también opera como «un privilegio 
frente a la mera incoación de todo procedimiento». Configura así, como ha entendido el «intérprete supremo de la Constitución» ${ }^{50}$, un verdadero límite a la jurisdicción que tiene un carácter absoluto y no meramente relativo. Estamos, pues, ante una excepción o límite constitucional al ejercicio por los jueces y tribunales de la potestad jurisdiccional que les otorga el art. 117.3 CE, que si bien se extiende, según el art. 4 de la Ley Orgánica 6/1985, de 1 de julio, del Poder Judicial, a «todas las personas, a todas las materias y a todo el territorio español», lo es «en la forma establecida en la Constitución y en las leyes». Y de la Constitución deriva directamente este límite a su ejercicio, de forma tal que el Tribunal que entiende en un litigio, rebasando los límites constitucionales o legales de sus atribuciones, no desarrolla una actividad válida. Además, los límites subjetivos de la jurisdicción exigen que no estén sustraídas a su ámbito las personas que hayan de intervenir como partes, y «en el caso del parlamentario su prerrogativa le sustrae absolutamente, no sólo por razón de la persona, sino también de la materia, cuando el objeto del proceso consiste en exigirle responsabilidad por expresiones proferidas en su actuación».

La conclusión del Tribunal Constitucional es ${ }^{51}$ que el órgano jurisdiccional cuando abre un proceso, si consta inicialmente que se está ejercitando una pretensión de responsabilidad que reúne los caracteres citados, puede vulnerar el derecho del art. 23.2 CE y también, en relación con sus efectos procesales, el del demandado a la tutela efectiva, puesto que en estos casos su prerrogativa constitucional determina la carencia absoluta de jurisdicción del órgano ante quien aquel proceso se plantea.

De resultas de todo ello, el Tribunal ha entendido que la carencia de jurisdicción para tramitar y conocer de una demanda civil de responsabilidad frente a un parlamentario por opiniones vertidas en el ejercicio de sus funciones constituye un fundamento constitucional para acordar la no apertura del proceso, y la decisión de abrirlo vulnera el derecho del parlamentario a la tutela judicial, que en este caso se concreta prescriptivamente en la inadmisión a limine de la demanda. El efecto impeditivo para la apertura de cualquier clase de proceso o procedimiento que tenga por objeto exigir responsabilidad a los parlamentarios «por opiniones manifestadas en el ejercicio de sus funciones» exigirá, según interpreta el juez de las leyes ${ }^{52}$, de una parte, constancia cierta de que se dan las circunstancias

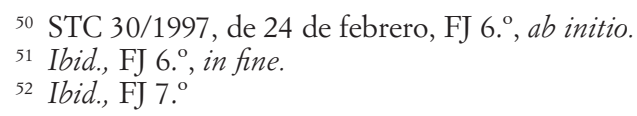


de hecho que configuran la prerrogativa, y también que la resolución judicial se dicte previa audiencia de la contraparte e invocando el motivo legal de la inadmisión in limine litis, como por otro lado establece el art. 9.6 de la Ley Orgánica del Poder Judicial.

\section{Naturaleza jurídico-penal de esta prerrogativa}

El Tribunal Constitucional no ha entrado a pronunciarse sobre la controvertida naturaleza, en el ámbito penal, de esta prerrogativa de la inviolabilidad, limitándose a recordar ${ }^{53}$ que mientras para unos es causa de inimputabilidad, para otros ha de ser considerada como una eximente de antijuridicidad. Esta falta de pronunciamiento jurisprudencial no obsta para que nos hagamos eco, siquiera sea de modo sumario, de las diferentes posturas doctrinales al respecto.

Como bien señalara Pizzorusso ${ }^{54}$, las inmunidades parlamentarias (genérica expresión con la que alude a lo que nosotros denominamos prerrogativas parlamentarias) se derivan de exigencias conectadas con la específica forma de gobierno vigente en un país y, en consecuencia, se insertan en la teoría del Derecho constitucional; sin embargo, aquéllas deben examinarse, por lo que concierne a su estructura técnica, desde el punto de vista del Derecho penal (la inviolabilidad) y del Derecho procesal penal (la inmunidad), a cuyos sistemas pertenecen.

El propio Pizzorusso ha enumerado ${ }^{55}$ las que entiende como tres categorizaciones jurídico-penales del instituto: causa personal de exención de la pena, causa de justificación y causa de exención de la punibilidad, para llegar, en último término, a la conclusión de que resulta difícil tomar partido por alguna de esas categorías, ya que el debate doctrinal lo que en realidad pone de manifiesto es la existencia de factores indudablemente contradictorios que son propios del instituto examinado, y que un análisis del mismo desde el punto de vista del Derecho constitucional contribuye a poner de relieve.

La doctrina alemana de los inicios del pasado siglo se decantó mayoritariamente por la consideración de esta prerrogativa como «causa personal

53 STC 51/1985, de 10 de abril, FJ 6. ${ }^{\circ}$

54 A. Pizzorusso, «Las inmunidades parlamentarias. Un enfoque comparatista», Revista de las Cortes Generales, núm. 2, segundo cuatrimestre de 1984, pp. 27 y ss., en concreto p. 39.

${ }^{5}$ Ibid., pp. 40-42. 
de exclusión de la pena», lo que entrañaba el mantenimiento de la antijuridicidad del acto, lo que a su vez se traducía en la punibilidad de los posibles copartícipes en el mismo, algo que si bien no parecía de recibo en la prerrogativa ahora examinada, sí podía ser útil, por ejemplo, en la prerrogativa de la inmunidad.

Como regla general, la doctrina penal española siguió esta línea interpretativa. Quintano Ripollés, bien que con anterioridad a la entrada en vigor de la Constitución, vino a considerar ${ }^{56}$ la inviolabilidad como una verdadera irresponsabilidad, lo que entrañaba mantener la antijuridicidad de la acción, excluyendo su punibilidad. Sin embargo, Rodríguez Devesa sostuvo $^{57}$ que la inviolabilidad era una causa de justificación, puesto que era un derecho de los parlamentarios que les venía conferido por su calidad de representantes del pueblo español. En esta misma dirección, Gómez Benítez ha tildado ${ }^{58}$ de saludable criterio la caracterización de la inviolabilidad como causa de justificación, amparada en el ejercicio de un derecho o cargo, frente al criterio obsoleto y «privilegiado» de su consideración como causa personal de exclusión de la pena. Y es que dentro del ámbito de cualquier causa excluyente del injusto hay que moverse siempre dentro de los límites establecidos.

La inviolabilidad parlamentaria, y ello nos parece la tesis más correcta, viene a suponer un «plus» con respecto a la libertad de expresión constitucionalmente consagrada y a la que tienen derecho todas las personas; «plus» que, como se ha significado ${ }^{59}$, viene referido a determinados delitos de expresión que conculcan bienes protegidos, de los que son depositarios determinadas instituciones. Pero dicho «plus» de libertad siempre estará sujeto a la «necesidad» de tales acciones para el cumplimiento de la respectiva función. Por ello, como ya tuvimos oportunidad de decir, resulta en extremo difícil comprender que, por ejemplo, las manifestaciones calumniosas puedan entenderse «necesarias» en el sentido antes asumido para el ejercicio de la función parlamentaria.

La jurisprudencia del Tribunal Supremo se ha decantado por este último criterio, al considerar la inviolabilidad parlamentaria como una causa

\footnotetext{
56 A. Quintano Ripollés, Curso de Derecho Penal, t. I, Madrid, Revista de Derecho Privado, 1963 , pp. $145-146$.

57 J. M. ${ }^{a}$ Rodríguez Devesa, Derecho Penal Español. Parte General, 17. ${ }^{a}$ ed., Madrid, Dykinson, 1994, p. 659.

${ }^{58}$ J. M. GÓmEz Benítez, «La inviolabilidad y la inmunidad parlamentarias», Revista de la Facultad de Derecho de la Universidad Complutense, núm. 64, invierno de 1982, pp. 25 y ss., en concreto p. 66.

59 Ibid., p. 67.
} 
de justificación, eliminatoria de la antijuridicidad de la acción por ampararse en el ejercicio de un derecho o $\operatorname{cargo}^{60}$.

\section{La imposible aplicación a la inviolabilidad de la técnica procesal de la inmunidad}

1. La Ley Orgánica 3/1985, de 29 de mayo, vino a modificar la Ley Orgánica 1/1982, de 5 de mayo, sobre protección del derecho al honor, a la intimidad personal y familiar y a la propia imagen, dando una nueva redacción al art. 2.2 de esta última ${ }^{61}$ mediante la adición de un nuevo inciso que, en esencia, venía a disponer que tampoco se apreciaría la existencia de intromisión ilegítima en el ámbito de los derechos protegidos «cuando se trate de opiniones manifestadas por diputados o senadores en el ejercicio de sus funciones», a cuyo efecto se añadía: «Iniciado un proceso civil en aplicación de la presente Ley, no podrá seguirse contra un diputado o senador sin la previa autorización del Congreso de los Diputados o del Senado. La previa autorización será tramitada por el procedimiento previsto para los suplicatorios».

En su breve Exposición de Motivos, la Ley justificaba la modificación introducida en la Ley Orgánica 1/1982 en el hecho de que, al amparo de este texto legal, «los parlamentarios podrían verse constantemente amenazados por la iniciación de procesos civiles que menoscaben su necesaria libertad para el ejercicio de sus funciones».

Ante el Tribunal Constitucional se iban a presentar en fechas relativamente próximas dos recursos de amparo (registrados con los núms. 602/1987 y 1566/1987, con fechas de 8 de mayo y 27 de noviembre, respectivamente), el primero, contra un Acuerdo del Pleno del Senado de fecha 18 de marzo de 1987, mediante el cual dicha Cámara resolvió no haber lugar a la concesión del suplicatorio para proceder civilmente contra un senador, y el segundo, contra el Acuerdo plenario del Congreso de los Diputados del día 23 de abril de 1987, por el que se denegó la autorización legalmente precisa a efectos de continuar las actuaciones

${ }^{60}$ Así, en la Sentencia del Tribunal Supremo de 22 de mayo de 1981.

${ }^{61}$ En su redacción originaria el precepto prescribía lo que sigue: «No se apreciará la existencia de intromisión ilegítima en el ámbito protegido (el ámbito de los derechos al honor, a la intimidad y a la propia imagen) cuando estuviere expresamente autorizada por ley o cuando el titular del derecho hubiere otorgado al efecto su consentimiento expreso», redacción que sigue teniendo hoy la misma norma. 
judiciales seguidas ante un Juzgado de Primera Instancia de Avilés frente a una diputada.

El primer recurso sería resuelto por la Sala Primera a través de la Sentencia 243/1988, por la que no sólo se otorgaba el amparo solicitado, declarando la nulidad del Acuerdo del Pleno del Senado, sino que también se acordaba elevar al Pleno una cuestión interna de inconstitucionalidad sobre el inciso introducido por la Ley Orgánica 3/1985. El segundo recurso fue resuelto por la Sala Segunda por medio de la Sentencia 186/1989, en términos muy semejantes a los de la decisión precedente, aunque ahora no se considerara necesario hacer uso de la facultad prevista por el art. 55.2 LOTC (Ley Orgánica del Tribunal Constitucional), puesto que ya la STC 243/1988 había procedido a elevar al Pleno del Tribunal la cuestión de inconstitucionalidad del ya mencionado inciso.

La cuestión interna de inconstitucionalidad sería finalmente resuelta por la Sentencia del Pleno del Tribunal 9/1990, que declararía inconstitucional la adición llevada a cabo por la Ley Orgánica 3/1985.

2. La cuestionada reforma legal entremezclaba los institutos de la inviolabilidad e inmunidad al proyectar la previa autorización de las Cámaras a que se refiere el art. 71.2 CE a los procesos civiles contra parlamentarios por opiniones manifestadas en el ejercicio de sus funciones, a las que alude el art. 71.1. El legislador orgánico introducía de esta forma, como el Tribunal iba a reconocer ${ }^{62}$, «una institución híbrida, compuesta a partir de elementos conceptuales de la inviolabilidad a los que se añade un instrumento autorizatorio, propio y exclusivo de la inmunidad, que carece de encaje constitucional y conlleva una irrazonable y desproporcionada limitación del derecho a la tutela judicial en cuanto impide el ejercicio independiente de la jurisdicción y, por tanto, resulta desprovista de la debida justificación, tanto desde la perspectiva del art. 71 de la Constitución como desde la que corresponde al art. 24.1 de la misma».

La norma acogida por la Ley Orgánica 3/1985 iba a ser considerada contraria a la Constitución tanto desde la óptica de la prerrogativa de la inviolabilidad como desde las exigencias de la garantía de la inmunidad. Por nuestra parte, nos limitaremos ahora a contemplar su inconstitucionalidad desde la óptica propia de la prerrogativa que estamos analizando, esto es, desde la garantía de la inviolabilidad parlamentaria, dejando para un momento ulterior el análisis de su ilegitimidad constitucional desde la comprensión del contenido de la inmunidad parlamentaria.

${ }^{62}$ STC 9/1990, de 18 de enero, FJ 5. ${ }^{\circ}$ 
Razona el Tribunal que, en cuanto la inviolabilidad es una garantía sustantiva, no procesal, que comporta la exclusión de responsabilidad jurídica de los diputados y senadores por las opiniones manifestadas en el ejercicio de su función parlamentaria, es obvio que en modo alguno requiere de la interposición de una autorización previa, que al carecer de expresa consagración constitucional sólo podría introducirse a través de una especie de vía analógica que, como ya dijimos, no consiente la interpretación estricta que se ha de dar a todas las prerrogativas parlamentarias, las cuales, como ha señalado el Tribunal Constitucional ${ }^{63}$, no suministran fundamento constitucional para condicionar o impedir la prestación de la función jurisdiccional con autorizaciones previas para proceder en el orden civil contra parlamentarios.

En una decisión posterior, el juez de las leyes insistiría en la idea de la incompatibilidad del instrumento de la autorización parlamentaria o suplicatorio con la naturaleza y alcance de la inviolabilidad. A la vista de la diferente caracterización y naturaleza de la inviolabilidad e inmunidad, el Tribunal argumenta ${ }^{64}$ que la única prerrogativa parlamentaria que puede justificar la suspensión y archivo de las actuaciones judiciales es la de la inmunidad, pues únicamente es esta institución la que constitucionalmente permite la exigencia de dicho presupuesto procesal. Y en otro lugar de la misma decisión, el Alto Tribunal consideraría que, siendo cierto que los parlamentarios —al igual que todas aquellas personas que intervienen en las contiendas políticas, o sean profesionales de la información o se dediquen a actividades en las que frecuentemente expresan opiniones o emiten informaciones con trascendencia pública que pueden afectar al honor, intimidad o imagen de otros ciudadanos- están expuestos al riesgo de tener que soportar demandas civiles por parte de las personas que consideren que las opiniones manifestadas por aquéllos entrañan intromisiones ilegítimas en sus referidos derechos fundamentales, «ello no constituye justificación razonable y proporcionada para establecer, en el orden procesal civil, un requisito en protección de los diputados y senadores que, en manifiesta contradicción con lo dispuesto en el art. 71 de la Constitución, pueda impedir el ejercicio del derecho a la tutela judicial, acudiendo al procedimiento de sustituir el privilegio de la inviolabilidad — garantía de naturaleza sustantiva que despliega su eficacia dentro del proceso [...] - por una exorbitante prerrogativa que traslada, más allá de las previsiones constitu-

\footnotetext{
${ }^{63}$ STC 243/1988, de 19 de diciembre, FJ 4. ${ }^{\circ}$, in fine.

${ }^{64}$ STC 9/1990, de 18 de enero, FJ 4. ${ }^{\circ}$, ab initio.
} 
cionales, la disponibilidad del proceso a un órgano no judicial y, con ello, la de la potestad jurisdiccional de controlar, sin injerencias extrañas, el uso que los parlamentarios hagan de su libertad de expresión y la aplicación al mismo de la garantía de la inviolabilidad» ${ }^{65}$.

Innecesario es decir, añadiríamos marginalmente, que los derechos y libertades no son absolutos, como una reiteradísima jurisprudencia constitucional ha puesto de manifiesto, pero si ello es así, menos aún puede atribuirse dicho carácter a las limitaciones a que ha de someterse el ejercicio de tales derechos. Como una vez más sostiene el Alto Tribunal ${ }^{66}$, tanto las «normas de libertad» como las llamadas «normas limitadoras» se integran en un único ordenamiento inspirado por los mismos principios en el que, en último término, resulta ficticia la contraposición entre el interés particular subyacente a las primeras y el interés público que, en ciertos supuestos, aconseja su restricción. Se produce, pues, un régimen de concurrencia normativa, que no de exclusión.

Esta concurrencia de normas deviene, en último término, de que tanto los derechos individuales como sus límites, en cuanto éstos derivan del respeto a la ley y a los derechos de los demás, son igualmente considerados por el art. 10.1 CE como «fundamento del orden político y de la paz social».

La concurrencia entre las «normas de libertad» y las «normas limitadoras» entraña que unas y otras operen con el mismo grado de vinculatoriedad y actúen recíprocamente. Como resultado de esta interacción, la fuerza expansiva de todo derecho fundamental restringe el alcance de las normas que establecen límites al ejercicio de un derecho; de ahí la exigencia, una y otra vez reiterada por el Tribunal, de que los límites de los derechos fundamentales hayan de ser interpretados con criterios restrictivos y en el sentido más favorable a la eficacia y a la esencia de tales derechos. Y de ahí precisamente la doctrina constitucional, a la que ya hemos hecho mención, que rechaza una interpretación expansiva de las prerrogativas parlamentarias a fin de que no devengan en privilegios que puedan lesionar derechos de terceros.

\footnotetext{
${ }^{65}$ Ibid., FJ 5. ${ }^{\circ}$

${ }^{66}$ Entre otras decisiones, en las SSTC 159/1986, de 12 de diciembre, FJ 6. ${ }^{\circ}$, y 254/1988, de 21 de diciembre, FJ 3. ${ }^{\circ}$
} 


\section{LA INMUNIDAD PARLAMENTARIA}

\section{Su caracterización como prerrogativa institucional}

La inmunidad parlamentaria es una prerrogativa de naturaleza formal que protege la libertad personal de los representantes populares contra detenciones y procesos judiciales que puedan desembocar en privación de libertad, evitando que, por manipulaciones políticas, se impida al parlamentario asistir a las reuniones de las Cámaras y, a consecuencia de ello, se altere indebidamente su composición y funcionamiento ${ }^{67}$. La protección hacia la que la inmunidad se orienta no lo es frente a la improcedencia o falta de fundamentación de las acciones penales dirigidas contra los diputados o senadores, pues, como dice el Tribunal ${ }^{68}$, no cabe mayor defensa frente a tales riesgos o defectos de tipo jurídico que la proporcionada por los jueces o tribunales a quienes el art. 117.1 CE atribuye, de manera específica, la tarea de aplicar el ordenamiento para la administración de justicia. Esto viene a significar que la amenaza frente a la que protege la inmunidad sólo puede serlo de tipo político y consiste en la eventualidad de que la vía penal sea utilizada con la intención de perturbar el funcionamiento de las Cámaras o de alterar la composición que a las mismas ha dado la voluntad popular. Ello, innecesario es decirlo, se podría conseguir a través de eventuales procesos penales que pudieran incoarse frente a los miembros de las Cámaras por actos producidos tanto antes como durante su mandato, en la medida en que de dichos procesamientos o inculpaciones pueda resultar la imposibilidad de un parlamentario de cumplir efectivamente sus funciones.

Al servicio del referido objetivo se establece la autorización del órgano parlamentario para proceder contra sus miembros, que es el instrumento propio y característico de la inmunidad, cuyo campo de actuación, por su finalidad, ha sido reconducido por el Tribunal al proceso penal, una vez desaparecida de nuestro ordenamiento jurídico la prisión por deudas y la privación de libertad derivada de actos administrativos. La posibilidad de que las Cámaras aprecien y eviten esa intencionalidad política es lo que la Constitución ha querido al otorgarles la facultad de impedir que las acciones penales contra sus miembros prosigan; esto es lo que justamente per-

${ }^{67}$ Entre otras, SSTC 243/1988, de 19 de diciembre, FJ 3. ${ }^{\circ}$, B), y 9/1990, de 18 de enero, FJ $\left.3 .^{\circ}, \mathrm{B}\right)$.

${ }^{68}$ STC 90/1985, de 22 de julio, FJ 6. 
mite la institución de la inmunidad: una valoración del significado político de tales acciones penales, que es precisamente lo que no pueden llevar a cabo los órganos de naturaleza jurisdiccional. Quiere todo ello decir que, en lo básico, la inmunidad es una prerrogativa parlamentaria que permite la suspensión o evitación de actuaciones judiciales ${ }^{69}$.

A la vista de todo lo que hemos venido exponiendo, es una obviedad hablar de la vertiente eminentemente institucional de la inmunidad. Ya hemos aludimos a tal rasgo, haciéndonos eco de cómo el Tribunal Constitucional ha puesto de relieve que el carácter objetivo de las prerrogativas parlamentarias se refuerza en el caso de la inmunidad, hasta el punto de poder sostenerse que ésta adquiere el sentido de una «prerrogativa institucional» ${ }^{70}$. Ello puede justificarse si se piensa en que la inmunidad de que gozan los diputados y senadores se encuentra conectada con la proclamación del art. 66.3 CE de que «las Cortes Generales son inviolables» ${ }^{71}$, y quizá por ello mismo esta prerrogativa, a diferencia de otras prerrogativas parlamentarias, es privativa y exclusiva de los miembros de las Cortes Generales de la nación española, como el Tribunal ya vino a entender en la primera decisión en que se ocupó de estas prerrogativas ${ }^{72}$.

El sentido institucional de esta prerrogativa es, por lo demás, el único susceptible de preservar su legitimidad ${ }^{73}$, pues es evidente que no puede ser contemplada como una vía para «generar zonas inmunes al imperio de la ley». Conviene, sin embargo, matizar que ese significado institucional no debe entenderse en el sentido de que el interés superior de la representación nacional deba imponerse, en todo caso, a la prosecución de la acción de la justicia. Así, y sin que ello suponga desconocer la lógica inherente al pluralismo político, «la inmunidad, como prerrogativa institucional, quedaría inmediatamente desnaturalizada si quedase a merced del puro juego del respectivo peso de las fracciones parlamentarias» ${ }^{74}$.

${ }^{69}$ El Tribunal Constitucional, en la importantísima Sentencia 206/1992, ha entendido que «la hipótesis de una intencionalidad hostil a la institución parlamentaria en la actuación judicial, determinante en los orígenes del instituto (fumus persecutionis), debe ser hoy considerado un supuesto no descartable, mas su capacidad de agotar el sentido del instituto supondría la restricción del mismo a unos límites que no parecen haber sido los queridos por el constituyente».

${ }^{70}$ STC 206/1992, de 27 de noviembre, FJ 3. ${ }^{\circ}$

71 A esta conexión se ha referido el Tribunal en varias decisiones; así, en las SSTC 206/1992, de 27 de noviembre, FJ 3. ${ }^{\circ}$, ab initio, y 123/2001, de 4 de junio, FJ 4. ${ }^{\circ}$

72 STC 36/1981, de 12 de noviembre.

73 Así lo ha admitido el Tribunal en diversas decisiones, como, por ejemplo, en la STC 123/2001, de 4 de junio, FJ $4 .^{\circ}$

74 STC 206/1992, de 27 de noviembre, FJ 3. ${ }^{\circ}$ 
La precedente afirmación no debe entenderse en el sentido antitético de que siempre que se requiera un suplicatorio a una Cámara parlamentaria, ésta venga obligada a concederlo para permitir el acceso a la justicia. Es preciso, por contra, reconocer que la prerrogativa de la inmunidad implica siempre una posibilidad de que sea denegado el derecho al proceso penal ${ }^{75}$. El Tribunal ha tenido oportunidad de señalar ${ }^{76}$ que una interpretación sistemática de los diversos preceptos constitucionales conduce a atribuir a las Cámaras y a sus miembros un amplio margen de libertad en el uso de estos «privilegios», dada su finalidad de asegurar el buen funcionamiento de las instituciones parlamentarias cuya importancia en un sistema democrático es decisiva ${ }^{77}$. Quizá la clave para armonizar los distintos derechos y bienes constitucionales en juego sea el atender no sólo a si existe una amenaza de intencionalidad política frente a la institución parlamentaria, sino también a la gravedad, trascendencia y circunstancias de los hechos imputados.

Innecesario es añadir que, en coherencia con ese carácter objetivo e institucional de que se reviste esta prerrogativa, no estamos ante un ius singulare; ya dijimos que ninguna prerrogativa parlamentaria puede catalogarse así, pero en este caso el rechazo de una visión de la inmunidad como privilegio aún pugnaría, en mayor medida si cabe que otras prerrogativas, con los valores de «justicia» e «igualdad» que el art. 1.1 CE reconoce como «superiores» de nuestro ordenamiento jurídico. Bien alejada de lo que constituiría un privilegio, «la inmunidad, en cuanto garantía del desempeño de la función parlamentaria, se integra, como reflejo de la que corresponde al órgano del que forma parte, en el status propio del cargo parlamentario, de modo que el derecho fundamental directamente afectado frente a posibles constricciones ilegítimas a aquella prerrogativa es el

75 STC 206/1992, de 27 de noviembre, FJ 3. ${ }^{\circ}$, in fine.

${ }^{76}$ ATC $147 / 1982$, de 22 de abril, FJ $5 .{ }^{\circ}$

77 Comentando el Auto del Tribunal 147/1982, Martín-Retortillo consideraría decisivo dar un amplio margen de libertad a la esfera reservada al Parlamento sin intromisiones. Por algo — añade este autor - habrá consagrado la Constitución el privilegio de la inviolabilidad. Por algo estamos ante el diseño de un Estado calificado constitucionalmente de parlamentario. Su conclusión es inequívoca: «Los privilegios funcionales traídos por la Constitución habilitan un amplio espacio de juego para el cometido parlamentario. Es así como cobra sentido pleno la doctrina del "amplio margen de libertad" cuya acuñación gramatical ya es un acierto». Vid. L. Martín-Retortillo Baquer, «El "amplio margen de libertad" en el uso de los privilegios parlamentarios y su incidencia sobre los derechos fundamentales (Auto del Tribunal Constitucional 147/1982, de 22 de abril, sobre el alcance de las "preguntas" parlamentarias)», Revista Española de Derecho Constitucional, núm. 11, mayo-agosto de 1984, pp. 121 y ss., en concreto pp. 133-134. 
recogido en el art. 23.2 CE, pues, en definitiva, se trata de preservar, frente a tales constricciones, uno de los elementos integrantes del estatuto propio del cargo» ${ }^{78}$.

\section{Diseño de la prerrogativa y contenido de la misma}

1. La inmunidad forma parte del texto constitucional con idéntica legitimidad a la del resto de los institutos constitucionales. Ocurre, sin embargo, que la Constitución no es la suma y el agregado de una multiplicidad de mandatos inconexos, sino precisamente el orden jurídico fundamental de

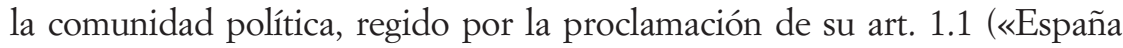
se constituye en un Estado social y democrático de Derecho, que propugna como valores superiores de su ordenamiento jurídico la libertad, la justicia, la igualdad y el pluralismo político»), a partir de la cual debe resultar un sistema coherente en el que todos sus contenidos encuentren el espacio y la eficacia que el constituyente quiso otorgarles. A todo ello añade el Tribunal en su Sentencia 206/1992 que «el sistema constitucional es ajeno a cualquier concepción jerarquizada, de forma más o menos latente, entre sus contenidos "dogmático" y "orgánico". Derechos fundamentales y estructura democrática son ambos expresiones y soporte del mismo y único modelo de comunidad política que, desde sus orígenes, la Constitución representa».

Esta reflexión general constituye un punto de referencia al que atender en la tarea de concretar y actualizar «un instituto característicamente vinculado a las condiciones históricas de afirmación y de consolidación del Estado de Derecho» ${ }^{79}$, labor tanto más necesaria cuanto que el art. 71.2 $\mathrm{CE}$ es especialmente conciso a la hora de recoger la figura de la inmunidad. Es ésta una tarea que implica a varios órganos, el Tribunal Constitucional entre ellos, pero primariamente al legislador, a quien le corresponde comprobar en qué medida las leyes procesales continúan adecuándose en su regulación a la norma constitucional vigente. Y muy particularmente —apreciará el Tribunal — están implicadas las propias Cámaras integrantes de las Cortes Generales, no ya sólo a través de su potestad reglamentaria, sino sobre todo a través de su tarea constante de formación de unos usos parlamentarios que siempre han sido consustanciales al régimen parlamentario y, por ende, al Estado de Derecho.

\footnotetext{
78 STC $123 / 2001$, de 4 de junio, FJ 3. ${ }^{\circ}$

79 STC 206/1992, de 27 de noviembre, FJ 3. ${ }^{\circ}$
} 
El protagonismo de las Cámaras en la tarea de lograr un perfil constitucionalmente adecuado de la institución de la inmunidad es decisivo, sin que ello permita olvidar que, al igual que los restantes poderes públicos, también las Cámaras están sujetas a la Constitución y al resto del ordenamiento jurídico (art. 9.1 CE), y en coherencia con tal sujeción, también a ellas les alcanza la interdicción de la arbitrariedad que consagra el art. 9.3 de la propia Constitución.

La realidad revela en España que el legislador posconstitucional ha permanecido silente en relación a la garantía que nos ocupa, excepción hecha de las concisas previsiones que los Reglamentos de ambas Cámaras han dedicado a la inmunidad, que en el caso del art. 11 del Reglamento del Congreso de los Diputados se limita a ser una mera transcripción literal del texto del art. 71.2 CE. Resulta sorprendente que, tal y como ya dijimos, sea un texto legal de un siglo de antigüedad el que aún rige en la materia. Se trata de la Ley de 9 de febrero de 1912, declarando los Tribunales que han de entender en el conocimiento de las causas contra senadores y diputados.

2. La inmunidad, como anteriormente expusimos, es una prerrogativa de naturaleza formal que protege la libertad personal de los parlamentarios frente a detenciones y procesos judiciales que pueden desembocar en privación de libertad. Configurándose así, esta prerrogativa opera constitucionalmente en un doble sentido:

A) Se concreta, ante todo, en la exención de cualquier posible detención de un diputado o senador en ejercicio de su mandato, con la sola salvedad del supuesto de flagrante delito. Como es fácilmente comprensible, la duda que surge de inmediato atañe al concepto de flagrancia delictiva.

El Tribunal tuvo oportunidad de pronunciarse en torno al significado de este concepto en su Sentencia 341/1993, en la que, aunque la cuestión enjuiciada nada tenía que ver con la materia que ahora nos ocupa, es lo cierto que las reflexiones jurisprudenciales sentadas en torno a ese concepto tienen un indudable interés. A partir de la idea de que la Constitución «no surge, ciertamente, en una situación de vacío jurídico, sino en una sociedad jurídicamente organizada ${ }^{80}$, algo que tiene especial valor cuando se trata de interpretar los conceptos jurídicos que el texto fundamental ha incorporado, que pueden tener, como ocurre con el de «flagrancia», un arraigo en la cultura jurídica en la que la Constitución se inscribe y que deben ser identificados, por tanto, sin desatender lo que el Tribu-

${ }^{80}$ STC 108/1986, de 29 de julio, FJ 16. 
nal tempranamente llamó las «ideas generalizadas y convicciones generalmente admitidas entre los juristas, los jueces y, en general, los especialistas en Derecho» ${ }^{81}$, el juez de las leyes ha reconocido la arraigada imagen de la «flagrancia» como «situación fáctica en la que el delincuente es "sorprendido" - visto directamente o percibido de otro modo- en el momento de delinquir o en circunstancias inmediatas a la perpetración del ilícito» ${ }^{82}$.

A tenor del art. 751 de la Ley de Enjuiciamiento Criminal, cuando el senador o diputado a Cortes fuere delincuente in fraganti podrá ser detenido y procesado sin la autorización del cuerpo colegislador a que pertenezca; pero en las veinticuatro horas siguientes a la detención o procesamiento deberá ponerse lo hecho en conocimiento del cuerpo colegislador a que corresponda. Indiscutiblemente, esta previsión de la Ley procesal criminal debe entenderse modulada por la determinación constitucional, que impide el procesamiento sin la previa autorización de la Cámara que corresponda.

La única posibilidad constitucionalmente permitida de detención en caso de flagrante delito ha variado de modo sustancial el planteamiento clásico; en éste la detención es siempre posible con autorización y el «delito flagrante» se utiliza como excepción a la regla, o sea, legitima la detención sin previa autorización. Al prescribir el art. 71.2 CE que «sólo podrán ser detenidos en caso de flagrante delito», sin hacer referencia alguna a la autorización, parece que el constituyente ha querido excluir cualquier otro caso de detención. Una conclusión de este género se ha entendido ${ }^{83}$ que equivale a hacer de los parlamentarios una casta totalmente distanciada del común de los ciudadanos, considerándose que la ratio de esta prerrogativa, la independencia de la función, no exige tanto, a cuyo efecto se postula una interpretación armónica del precepto de acuerdo con la cual la autorización parlamentaria para procesar comprendería al propio tiempo la autorización para detener o para, en su caso, decretar la prisión provisional que la Ley de Enjuiciamiento Criminal prevé como anejas al procesamiento. Por nuestra parte, no creemos deban entremezclarse los dos contenidos que la prerrogativa acoge constitucionalmente y que son objeto de un tratamiento jurídico diferente.

B) La prerrogativa de la inmunidad viene, en segundo término, a condicionar la viabilidad de toda acción penal emprendida contra diputa-

${ }^{81}$ STC 11/1981, de 8 de abril, FJ 8. ${ }^{\circ}$

82 STC 341/1993, de 18 de noviembre, FJ 8. $\left.{ }^{\circ}, \mathrm{B}\right)$.

83 E. ReCODER DE CASSO, «Comentario al artículo 71 de la Constitución», en F. GarRIDo Falla et al., Comentarios a la Constitución, 3. ${ }^{a}$ ed., Madrid, Civitas, 2001, pp. 1183 y ss., en concreto pp. 1189-1190. 
dos o senadores, operando como requisito inexcusable de procedibilidad al exigir la previa concesión del suplicatorio. Siendo ello así, es claro que las propias Cámaras parlamentarias, al pronunciarse sobre la pertinencia o no del suplicatorio interesado, han de tener presente, según el Alto Tribunal ${ }^{84}$, la naturaleza de la acción penal y decidir motivadamente acerca de si, mediante su interposición, se pretende una utilización instrumental del proceso penal para alcanzar propósitos meramente políticos y tendentes a alterar la composición democrática de la Cámara. De esta forma, el instituto de la inmunidad supone una paralización, siquiera sea temporal, de la acción de la justicia.

De esta naturaleza de la inmunidad como condición de procedibilidad ha derivado Pizzorusso ${ }^{85}$ que la inmunidad opera exclusivamente en el ámbito del proceso, de modo que la falta de concesión de la autorización parlamentaria no impide la reinterposición de la acción, una vez que el obstáculo haya desaparecido, por la conclusión del periodo de sesiones o de la legislatura, o por la dimisión de su cargo por parte del parlamentario. $\mathrm{El}$ propio autor, en otro lugar ${ }^{86}$, argumenta que no estamos ante una eximente y sí sólo ante una causa temporal de improcedibilidad de la acción penal, acción cuya efectividad queda diferida hasta el momento en que se conceda la autorización parlamentaria o, en su defecto, hasta el término de la legislatura, a no ser que se produzca la reelección.

En suma, la inmunidad no sería una causa de exclusión de la responsabilidad penal, como básicamente lo es la inviolabilidad, sino una causa de suspensión del proceso penal que lleva aparejada la suspensión de la prescripción del delito ${ }^{87}$. Como en análoga dirección advertiría Rodríguez Devesa ${ }^{88}$, cuando el diputado o senador pierde su condición de tal cesa de operar el óbice procesal.

Esta naturaleza se sustenta en la propia función constitucional del instituto: si la inmunidad ampara a la institución parlamentaria, el libre ejercicio de sus funciones, o dicho de otro modo, si no se trata de un privilegio personal, sino de un instrumento de salvaguarda de la organización y

${ }^{84}$ STC 22/1997, de 11 de febrero, FJ 7. ${ }^{\circ}$

85 A. Pizzorusso, «Las inmunidades parlamentarias...», op. cit., p. 42.

86 A. Pizzonusso, Lecciones de Derecho Constitucional, t. I, Madrid, Centro de Estudios Constitucionales, 1984, p. 279.

${ }_{87}$ M. Cavero Gómez, «La inmunidad de los diputados del Parlamento Europeo», Revista de las Cortes Generales, núm. 20, segundo cuatrimestre de 1990, pp. 7 y ss., en concreto p. 27.

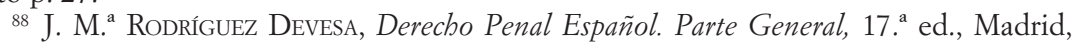
Dykinson, 1994, p. 660. 
funcionamiento de las Cámaras, parece lógico concluir que, una vez que el parlamentario deje de serlo, desaparecerá el obstáculo que impedía proceder contra él.

En nuestro ordenamiento jurídico existe, sin embargo, un obstáculo frente a tal conclusión. Es cierto que el art. 754 de la Ley de Enjuiciamiento Criminal dispone que «si el Senado o el Congreso negasen la autorización pedida, se sobreseerá respecto al senador o diputado a Cortes, pero continuará la causa contra los demás procesados». Sin embargo, la ya mencionada Ley de 9 de febrero de 1912, por la que se regulan la jurisdicción y el modo de proceder contra los senadores y diputados por razón de delito, dispone en el inciso primero de su art. 7 que «si el Senado o el Congreso denegasen la autorización para procesar, se comunicará el acuerdo al Tribunal requirente, que dispondrá el sobreseimiento libre respecto al senador o diputado». El sobreseimiento libre supone en la práctica el archivo definitivo de la causa y la imposibilidad de reabrirla una vez expirado el mandato parlamentario.

El libre sobreseimiento viene de esta forma a alterar la naturaleza jurídica de la inmunidad, que de ser una causa de improcedibilidad, tal y como vimos sostiene un sector de la doctrina, se transforma en una causa de exclusión de la responsabilidad penal, transformación ésta de más que dudoso acomodo al significado que en nuestro tiempo ha de tener el instituto analizado y aun diríamos que dudosamente acorde con la propia disposición constitucional ${ }^{89}$. Amplios sectores de la doctrina convergen en estas apreciaciones. Así, Gómez Benítez ${ }^{90}$, lisa y llanamente, entiende que la denegación del suplicatorio no produce efectos materiales de exención de responsabilidad, sino sólo de imposibilidad temporal de proceder penalmente contra el parlamentario mientras dure su función, es decir, su status. Y Carro Martínez se mostraría favorable a que la inmunidad interrumpiera tan sólo el plazo de prescripción del delito imputado, de manera que una vez cesada la función parlamentaria no quedara consagrada la impunidad ${ }^{91}$.

\footnotetext{
${ }^{89}$ Con el sobreseimiento libre — ha escrito con evidente razón Abellán— nuestra legislación extravasa los límites propios de la inmunidad, por cuanto supone una desnaturalización y un abuso de la misma y contradice el art. 71.2 CE, que la extiende sólo al tiempo de mandato del parlamentario. Esta regulación, concluye el citado autor, no es aceptable en un Estado de Derecho, contrariando los arts. 14 y 24.1 de nuestra Norma suprema. Vid. M. Á. Abellán, El estatuto de los parlamentarios..., op. cit., pp. 127-128.

90 J. M. Gómez BENÍTEZ, «La inviolabilidad y la inmunidad...», op. cit., p. 75.

91 A. Carro Martínez, «La inmunidad parlamentaria», Revista de Derecho Político, núm. 9, primavera de 1981, pp. 87 y ss., en concreto p. 108.
} 
La disfuncionalidad de la fórmula legal acuñada en 1912 se pone aún más de manifiesto si se confronta con algunas de las previsiones de la Ley de Enjuiciamiento Criminal. Ya hemos aludido a su art. 754, que no califica el sobreseimiento en el caso que nos ocupa de libre. Adicionalmente, el art. 637, que contempla los supuestos de procedencia del sobreseimiento libre, no se refiere al sobreseimiento en el caso de denegación del suplicatorio de un parlamentario. Todo ello no hace sino poner de manifiesto la inexcusabilidad de una nueva regulación procesal de esta cuestión.

El Tribunal Constitucional ha convalidado, por así decirlo, la interpretación más discutible del instituto de la inmunidad parlamentaria. A la vista del citado art. 7 de la centenaria Ley de 1912, y de su determinación de que el sobreseimiento será «libre», lo que, como es obvio, significa un sobreseimiento libre de actuaciones, el alto órgano jurisdiccional ha entendido que «no cabe, por tanto, la posibilidad de un nuevo procesamiento, pues tal sobreseimiento, que implica los efectos de cosa juzgada material, así lo impide por sí mismo» ${ }^{92}$. Esta posición no ha variado con el paso del tiempo, y así, tres lustros más tarde, el Tribunal sigue argumentando que el efecto de la denegación por las Cámaras de la autorización para inculpar o procesar a un diputado o senador es únicamente «la imposibilidad de continuar el procedimiento contra la persona aforada en relación con la que no se ha concedido la autorización para su inculpación o procesamiento, debiendo dictar, precisamente, la propia Sala auto de procesamiento libre respecto a ella» ${ }^{93}$.

\section{Su ámbito material}

Ya Barthélemy y Duez, en su clásico Tratado 94 , hicieron hincapié en la restricción del ámbito material de operatividad de la prerrogativa parlamentaria de la inmunidad a los procesos penales, subrayando que la inmunidad no salvaguardaba al parlamentario más que contra las persecuciones represivas por crimen o delito, por lo que esta garantía no obstaculizaba las acciones civiles.

En España, el Tribunal Constitucional iba a hacer suya esta doctrina en la primera oportunidad que se le iba a presentar de abordar el tema.

\footnotetext{
${ }^{92}$ STC 92/1985, de 24 de julio, FJ 5. ${ }^{\circ}$, ab initio.

93 STC 123/2001, de 4 de junio, FJ 8. ${ }^{\circ}$

${ }^{94}$ J. Barthélemy y P. Duez, Traité de Droit Constitutionnel, op. cit., p. 570.
} 
Esa ocasión la iba a propiciar la ya con anterioridad mencionada reforma de la Ley Orgánica 1/1982, de 5 de mayo, de protección civil del derecho al honor, a la intimidad personal y familiar y a la propia imagen, llevada a cabo por la Ley Orgánica 3/1985, de 29 de mayo. Aunque ya nos hicimos eco del texto reformado del art. 2.2 de la Ley Orgánica 1/1982, recordaremos ahora, en relación con lo que interesa, que el mencionado precepto venía a establecer que, una vez iniciado un proceso civil en aplicación de la Ley de Protección Civil del Derecho al Honor, tal proceso no podría seguirse contra un diputado o senador sin la previa autorización del Congreso de los Diputados o del Senado, autorización que había de ser tramitada por el procedimiento previsto para los suplicatorios.

Un recurso de amparo promovido contra un Acuerdo del Pleno del Senado de fecha 18 de marzo de 1987, mediante el cual dicha Cámara resolvía no haber lugar a la concesión del suplicatorio para proceder civilmente contra un senador, desencadenaba el pronunciamiento del Tribunal acerca de la cuestión que nos ocupa.

Tras constatar lo obvio, que los demandantes de amparo habían visto fracasada la tramitación de su demanda civil y, por ello, la realización del contenido normal de su derecho a la tutela judicial, no por haber omitido el cumplimiento de requisitos y presupuestos generales del proceso que intentaron, sino porque, al ser dirigida la demanda contra un parlamentario, el órgano judicial entendió, en aplicación del art. 2.2 de la LO 1/1982, en la redacción que le había dado la LO 3/1985, que no podía dar curso a la demanda sin obtener previamente la autorización de la Cámara, «condicionando así la viabilidad de la pretensión a un requisito excepcional y privilegiado que sólo será conforme al derecho invocado si cuenta con un fundamento constitucional positivo, pues sólo en la Constitución podrá hallarse la razón jurídica de una restricción semejante a la obtención de la tutela judicial» ${ }^{95}$.

La respuesta que el Tribunal va a dar frente al citado condicionamiento no va a dejar lugar a dudas: «La inmunidad parlamentaria — argumenta el "intérprete supremo de la Constitución" 96 - se manifiesta inapropiada para impedir el curso de una demanda civil interpuesta contra un parlamentario, pues el sentido propio de las palabras empleadas por el art. 71 de la Constitución, los antecedentes históricos y legislativos de esa prerro-

\footnotetext{
${ }^{5}$ STC 243/1988, de 19 de diciembre, FJ 4. ${ }^{\circ}$

96 Ibid. Esta misma doctrina es reiterada en el ATC 1326/1988, de 19 de diciembre, FJ 2. $\left.{ }^{\circ}, \mathrm{b}\right)$.
} 
gativa de los miembros de las Cámaras y la razón misma de la institución excluyen, con absoluta claridad, que su protección se extienda a procesos que no sean penales, es decir, que no entrañen la eventualidad de que sean utilizados con la intención de perturbar el funcionamiento de la Cámara o alterar su composición mediante la posible privación de la libertad del parlamentario» ${ }^{97}$. Se sigue de ello lógicamente que la «previa autorización» que requiere el art. 71.2 CE para inculpar o procesar a diputados o senadores no puede exigirse para la admisión, tramitación y resolución de demandas civiles que en nada pueden afectar a su libertad personal y, en consecuencia, que la extensión al ámbito civil de dicha garantía procesal resulta constitucionalmente ilegítima.

Proyectando esa doctrina al caso concreto, el Tribunal iba a considerar que el acto recurrido fue adoptado con apoyo en una disposición de ley que exige la previa autorización, cuya denegación, considerada en sí misma, iba a declarar contraria al derecho fundamental a la tutela judicial ${ }^{98}$. Tras otorgar el amparo solicitado, el Alto Tribunal, como ya dijimos, planteaba una cuestión interna de inconstitucionalidad a fin de que el Pleno se pronunciara sobre la inconstitucionalidad de la referida norma.

El Pleno del Tribunal iba a resolver la cuestión interna de inconstitucionalidad planteada por la Sala en la Sentencia 9/1990, a la que ya nos hemos referido. La doctrina sentada en el Pleno armoniza perfectamente con la fijada por las dos Salas al pronunciarse sobre los recursos de amparo a los que ya hemos tenido oportunidad de aludir. «La inmunidad parlamentaria —argumentará el Pleno del Tribunal- ${ }^{99}$ se manifiesta inapropiada para impedir el curso de una demanda civil interpuesta contra un parlamentario, pues el sentido propio de las palabras empleadas por el art. 71 de la

${ }^{97}$ La doctrina que se pronunció en torno a esta problemática se manifestó en la misma dirección que el Tribunal. Así, para Fernández-Miranda sólo una interpretación inconciliable con el rigor del lenguaje jurídico permitiría identificar el término «procesado» con el de «demandado» o trasladar el término «inculpado» al ámbito del Derecho civil. Cfr. al respecto A. FERnÁndeZ-Miranda y CAMPOAMOR, «Del intento de ampliar el ámbito material de la inmunidad parlamentaria a determinados procedimientos civiles», Revista Española de Derecho Constitucional, núm. 12, septiembre-diciembre de 1984, pp. 9 y ss., en concreto p. 19.

${ }^{98}$ En la Sentencia 186/1989, en la que, como ya se dijo, el Tribunal vino a conocer de un caso muy semejante al resuelto por la Sentencia 243/1988, otorgando también el amparo demandado, se afirmaba: «No es tanto el contenido del acto parlamentario (igualmente denegatorio de la autorización solicitada para, en este caso, continuar las actuaciones judiciales seguidas frente a una diputada), sino la exigencia misma de ese acto lo que ha vulnerado el derecho a la tutela judicial del solicitante de amparo "al hacerse depender la tramitación de su demanda de un presupuesto procesal privilegiado y excepcional que no encuentra legitimidad en la Constitución"» (STC 186/1989, de 13 de noviembre, FJ 2. ${ }^{\circ}$ ).

${ }^{9}$ STC 9/1990, de 18 de enero, FJ 4. ${ }^{\circ}$ 
Constitución y la razón misma de la institución excluyen, con absoluta claridad, que su protección se extienda a procesos que no sean penales; es decir, que no entrañen la eventualidad de que sean utilizados con la intención de perturbar el funcionamiento de la Cámara o alterar su composición mediante la posible privación de libertad del parlamentario».

En coherencia con la argumentación precedente, el Alto Tribunal considera que la «previa autorización» que requiere el art. 71.2 «no puede exigirse para la admisión, tramitación y resolución de demandas civiles que en nada pueden afectar a la libertad personal de los parlamentarios y, en consecuencia, que la extensión del ámbito civil de dicha garantía procesal resulta constitucionalmente ilegítima».

En definitiva, la interpretación estricta que ha de darse a todas las prerrogativas parlamentarias, y por lo mismo también a la inmunidad, impide que esta garantía suministre fundamento constitucional para condicionar o impedir la prestación de la función jurisdiccional con autorizaciones previas para proceder en el orden civil contra parlamentarios. Con la reforma introducida el año 1985 en la Ley Orgánica 1/1982, el legislador pareció ignorar algo tan elemental como que las prerrogativas no son privilegios al servicio del interés particular de los parlamentarios, sino que responden a un único, exclusivo y excluyente interés institucional.

\section{El momento de solicitud a la Cámara del suplicatorio}

1. El art. 755 de la Ley de Enjuiciamiento Criminal prescribe que la autorización de la Cámara que corresponda para que uno de sus miembros sea inculpado o procesado «se pedirá en forma de suplicatorio, remitiendo con éste, y con carácter reservado, el testimonio de los cargos que resulten contra el senador o diputado, con inclusión de los dictámenes del fiscal y de las peticiones particulares en que se haya solicitado la autorización».

Una cuestión que queda un tanto al margen de la precisión legal es la del momento a partir del cual se hace necesario en un proceso penal solicitar el suplicatorio para inculpar o procesar a un diputado o senador. La cuestión se planteó ante el Alto Tribunal a raíz de un recurso de amparo promovido contra la Sentencia 1/1997 de la Sala Segunda del Tribunal Supremo, dictada el 28 de octubre de 1997, en una causa seguida, entre otros, contra un diputado (que es quien recurriría en amparo) por los delitos de falsedad en documento mercantil, asociación ilícita, delito fiscal, apropiación indebida y otros. 
Entre otras quejas, el diputado demandante de amparo adujo que el criterio vacilante mantenido por la Sala Segunda del Tribunal Supremo en cuanto al momento en que debía dirigir a la Cámara el suplicatorio - que le llevó, en un primer momento, a entender que era preciso formular y remitir el suplicatorio antes de pronunciarse sobre la admisión a trámite de la querella, permitiendo posteriormente (tras aceptar un recurso de súplica del Ministerio Fiscal) la instrucción de la causa durante años sin solicitar la pertinente autorización a través del suplicatorio- no era correcto por diversos motivos, entre otros, porque no era posible hacer una identificación entre inculpación y procesamiento como había hecho el Tribunal Supremo, pues para adquirir la situación de inculpado no se precisa la existencia de «indicios de criminalidad», siendo el sentido teleológico del art. 71.2 CE que la decisión parlamentaria sobre la autorización (como presupuesto de perseguibilidad) se produzca, a ser posible, en los albores de la instrucción y no con su finalización. Contra el criterio adoptado por la resolución judicial impugnada en amparo, adujo el demandante que la situación de «inculpado» se adquiere desde el mismo momento de la admisión a trámite de una querella, pues ello implica una evaluación de los hechos a que se refiere y a las personas supuestamente protagonistas. En consecuencia, desde la admisión de las querellas existió imputación judicial contra el recurrente de amparo y por ello era exigible, desde ese mismo momento procesal, formular el oportuno suplicatorio al Congreso de los Diputados. Al no hacerlo así, el Tribunal Supremo, según el demandante, lesionó sus derechos a un proceso público con todas las garantías y al juez ordinario predeterminado por la ley del art. 24.2 CE.

2. El Tribunal Constitucional iba a comenzar reconduciendo su enjuiciamiento a determinar si la interpretación y aplicación hecha por la Sala Segunda del Tribunal Supremo de la prerrogativa de la inmunidad resultaba contraria al art. 71.2 CE y, por consiguiente, vulneraba el derecho del art. 23.2 CE (derecho a acceder a los cargos públicos), no el derecho contemplado por el art. 24.2 (como aducía el demandante).

Constata el Tribunal que del art. 71.2 CE sólo cabe inferir, «que más que en un momento procesal concreto y preciso, la autorización a la Cámara respectiva ha de ser solicitada en todo caso antes de que los diputados y senadores sean inculpados o procesados, sin que el texto constitucional aporte criterio alguno en orden a la interpretación de estas dos últimas expresiones» ${ }^{100}$. El Tribunal recuerda que, pese al llamamiento efectua-

100 STC 123/2001, de 4 de junio, FJ 5. ${ }^{\circ}$ 
do en diversas sentencias ${ }^{101}$ al legislador sobre la inseguridad jurídica que comporta la situación legal existente en torno a las prerrogativas parlamentarias, el legislador posconstitucional no ha procedido al oportuno desarrollo, recogiéndose como única referencia en la normativa preconstitucional reguladora de la prerrogativa de la inmunidad, en cuanto al momento de solicitar la autorización a las Cámaras, la genérica referencia del art. 750 de la Ley de Enjuiciamiento Criminal al juez o Tribunal «que encuentre méritos para procesar a un senador o diputado a Cortes por causa de delito», y la mención del art. 5 de la Ley de 9 de febrero de 1912 de que el suplicatorio se dirigirá al cuerpo colegislador correspondiente, «acompañando testimonio de las actuaciones que se estimen necesarias».

En este marco normativo, la Sala Segunda del Tribunal Supremo, a lo largo de la instrucción y en la sentencia que puso fin a la causa, vino entendiendo que el momento de la admisión de las querellas no era el de solicitar el suplicatorio, sin perjuicio de su notificación a la persona o personas contra las que se dirigen a los efectos de ejercitar el derecho de defensa, interpretación que el Tribunal Constitucional consideraría acorde con los fines de la institución, dado que es preciso determinar si la denuncia o querella tiene o no fundamento.

La Sala Segunda del Tribunal Supremo fue aún más allá en su interpretación del momento procesal pertinente para solicitar la autorización de la Cámara, procediendo a tal efecto a interpretar los términos «inculpados o procesados» del art. 71.2 CE. En relación al segundo de ellos, la Sala consideraría que el término «procesados» tiene una realidad legislativa procesal inequívoca en el art. 384 de la Ley de Enjuiciamiento Criminal ${ }^{102}$, de modo que en el llamado proceso ordinario el suplicatorio habría de solicitarse en cuanto existieran indicios racionales de criminalidad, que son el soporte del procesamiento. Respecto al término «inculpados», que a diferencia del anterior estima la Sala que carece de una realidad legislativa inequívoca, consideró que la condición de inculpado no se identifica con la de querellado y que para que tal situación procesal se produzca es necesario un juicio judicial de inculpación, obviamente provisional, con base en la existencia de indicios racionales de criminalidad o fundadas sospechas o serios indicios de la participación, en cualquiera de sus formas, en

101 Así, en las SSTC 206/1992, de 27 de noviembre, FJ 3.․, y 22/1997, de 11 de febrero, FJ $4 .^{\circ}$

102 A tenor del inciso inicial del párrafo primero de ese art. 384: «Desde que resultare del sumario algún indicio racional de criminalidad contra determinada persona, se dictará auto declarándola procesada». 
un hecho penal, lo que puede requerir y hacer necesario una previa investigación judicial.

Esta interpretación venía a significar que la condición de «inculpado» no se adquiere con la mera admisión de una querella, sino que requiere un juicio judicial de inculpación, lo que a su vez exige una previa investigación judicial en orden a la determinación de la relevancia penal de los hechos y a la participación en los mismos de las personas aforadas contra las que se dirige la querella, dándoles, eso sí, traslado de la denuncia o querella al objeto de que, de acuerdo con el art. 118 de la Ley de Enjuiciamiento Criminal, puedan ejercer el derecho de defensa.

Para el Tribunal Constitucional, esta interpretación jurisprudencial llevada a cabo por la Sala Segunda del Tribunal Supremo del término «inculpados»y, por consiguiente, la exigencia de que existan indicios racionales de criminalidad o sospechas fundadas o verosímiles sobre la participación de un diputado o senador en los hechos objeto de investigación penal para que entre en juego la exigencia previa de autorización de la Cámara para su inculpación o procesamiento, en sí mismas consideradas, no pueden ser en modo alguno tildadas de contrarias o desconocedoras de la finalidad institucional a la que sirve la prerrogativa de la inmunidad. Y ello toda vez que el alcance conferido por dicha interpretación al término «inculpado» a los efectos del art. 71.2 CE no afecta al mandato representativo del parlamentario en cuanto no le imposibilita e impide el desempeño de sus funciones parlamentarias, con lo que ninguna incidencia tiene en la composición y funcionamiento de las Cámaras ${ }^{103}$.

La prerrogativa de la inmunidad, concluye el Alto Tribunal, no impide que el juez pueda investigar, pero veda la realización de actos que en sí mismos determinen la sujeción de un parlamentario a un procedimiento penal, ya sea mediante la expresión de un juicio formal de inculpación o a través de la práctica de otras diligencias que materialmente entrañen ese mismo significado. Quiere ello decir que desde el momento en que el juez cuente con elementos suficientes para adoptar alguno de los referidos actos, está obligado a solicitar inmediatamente el suplicatorio.

103 STC 123/2001, de 4 de junio, FJ 5. ${ }^{\circ}$ 


\section{El pronunciamiento parlamentario sobre el suplicatorio. Sus exigencias desde la perspectiva constitucional}

1. El art. 71.2 de la Constitución atribuye a las Cámaras parlamentarias una facultad consistente en conceder o no la autorización para encausar por vía penal a sus miembros, y como ha reconocido el Tribunal Constitucional ${ }^{104}$, no puede discutirse que ésta sea una facultad de la que las Cámaras disponen libremente, al igual que puede decirse de otras facultades que derivan directamente de la Constitución para las Cámaras o para otros órganos políticos, en relación a las cuales no se señalan condiciones específicas para su ejercicio. Es claro, como ya tuvimos ocasión de decir, que la Constitución ha querido que sean las propias Cámaras las que aprecien por sí mismas, a la vista de las circunstancias de cada caso concreto, si la inculpación o procesamiento de uno de sus miembros pretende producir el resultado objetivo de alterar indebidamente su composición o funcionamiento; se trata, pues, de una valoración política en la que las Cámaras no pueden ser sustituidas por los órganos jurisdiccionales. Ahora bien, el libre ejercicio de esta facultad en modo alguno exime a las Cámaras de atender en su pronunciamiento a la ratio a la que el instituto de la inmunidad responde. De esta forma, las propias Cámaras, al pronunciarse sobre la pertinencia o no del suplicatorio interesado, han de tener presente la naturaleza de la acción penal y decidir motivadamente acerca de si, mediante su interposición, se pretende una utilización instrumental del proceso penal para alcanzar propósitos meramente políticos y tendentes a alterar la composición democrática de la Cámara en cuestión.

Por lo demás, la libre capacidad decisoria de las Cámaras no entraña, como es obvio por otro lado, su desvinculación del principio de sometimiento a la Constitución, que, con carácter general, impone su art. 9.1 a todos los poderes públicos. En virtud de este principio, cualquier acto del Parlamento con relevancia jurídica externa, esto es, que afecte a situaciones que excedan del ámbito estrictamente propio del funcionamiento interno de las Cámaras, queda sujeto no sólo a las normas de procedimiento que en su caso establezca la Constitución, sino, asimismo, al conjunto de normas materiales que en la misma Constitución se contienen.

No puede caber duda alguna acerca de la relevancia jurídica externa del acto parlamentario a que venimos refiriéndonos, por cuanto el mismo

${ }^{104}$ STC 90/1985, de 22 de julio, FJ 2. ${ }^{\circ}$ 
puede suponer una paralización, siquiera temporal, de la acción de la justicia y, en su caso, del derecho fundamental a la tutela de los jueces, afectando de esta forma a uno de los pilares básicos del Estado de Derecho, como es el sometimiento de todos al imperio de la ley.

Se ha especulado que, en cuanto son los órganos judiciales los que han de otorgar la tutela judicial efectiva, sólo a ellos cabría imputar la violación de ese mismo derecho que la Constitución reconoce en su art. 24.1. Pero aunque ello pueda ser así en la mayoría de los casos, no cabe descartar que la vulneración de ese derecho del art. 24.1 se produzca directamente por órganos que no sean de naturaleza jurisdiccional. Esta circunstancia se produce justamente en el supuesto que nos ocupa.

La inmunidad se traduce en que, en relación a los delitos presuntamente cometidos por los diputados o senadores, sea la correspondiente Cámara la que decida acerca de la posibilidad de perseguir o no dichos delitos ante la jurisdicción penal. Ello equivale a decir que, en tales supuestos, son los órganos parlamentarios quienes adoptan decisiones acerca del acceso a la tutela judicial por parte de los ciudadanos afectados por las conductas supuestamente delictivas. De ahí que el Alto Tribunal haya podido decir ${ }^{105}$ que «la disponibilidad del proceso penal se convierte, de esta manera, en el objeto sobre el que deciden dichos órganos parlamentarios, de los que no puede afirmarse, en consecuencia, que sean ajenos a la prestación de la tutela judicial. Ésta, por el contrario, dependerá, en último término, de una actuación parlamentaria - la que conceda o deniegue el suplicatorio-, actuación que adquiere relieve jurisdiccional y es, por tanto, susceptible de examen desde la perspectiva del art. 24.1 CE».

En ocasiones se ha esgrimido ante el Tribunal Constitucional que el demandante de amparo por una supuesta violación de su derecho a la tutela judicial, de resultas de la denegación del suplicatorio por una Cámara, no se vería en la situación de indefensión en que fundamenta su demanda, toda vez que el actor habría dispuesto de otras posibilidades para obtener la tutela judicial de los derechos e intereses legítimos que considera lesionados. Pero frente a tal argumento, el Tribunal Constitucional ha replicado que el mandato contenido en el art. 24.1 CE («Todas las personas tienen derecho a obtener la tutela efectiva de los jueces y tribunales en el ejercicio de sus derechos e intereses legítimos sin que, en ningún caso, pueda producirse indefensión») encierra «el derecho a escoger la vía judicial que se estime más conveniente para la defensa de derechos e intere-

${ }^{105}$ Ibid., FJ 4. $^{\circ}$ 
ses legítimos, aunque sólo sea porque no puede decirse que sean los mismos los efectos y consecuencias jurídicas que ofrecen los distintos tipos de procesos previstos en nuestro ordenamiento para la defensa de tales derechos e intereses» ${ }^{106}$.

En definitiva, la institución de la inmunidad se hace efectiva mediante actuaciones que son, por el órgano que las lleva a cabo, de naturaleza parlamentaria, pero que adquieren también significado procesal desde el punto de vista del derecho a la jurisdicción ${ }^{107}$, en cuanto suponen, dentro del procedimiento penal, un elemento diferenciador, como es la necesidad de que las Cámaras respectivas den a la jurisdicción competente autorización para procesar en el supuesto de que una acción penal se dirija frente a un diputado o senador.

2. A la vista de la doctrina expuesta es claro que la posibilidad de conceder o denegar suplicatorios para procesar a parlamentarios en que el instituto de la inmunidad se concreta queda vinculada a la función de impartir justicia y, por tanto, le son aplicables los parámetros del art. 24.1 CE. Ello se traduce en una serie de exigencias que ha de cumplir el acto parlamentario llevado a cabo en aplicación del art. 71.2 CE.

La primera cuestión a dilucidar es la del alcance que el derecho a la tutela judicial presenta en relación al ejercicio de la facultad de las Cámaras parlamentarias de pronunciarse acerca del suplicatorio. La solución pasa por atender a una consolidada doctrina constitucional: la de que «el art. 24.1 de la Constitución debe aplicarse en cada caso según la naturaleza y fines de cada tipo de procedimiento» ${ }^{108}$.

Esta doctrina, de acentuado carácter finalista, implica la exigencia de que los recortes o limitaciones del derecho a la jurisdicción hayan de aparecer, en último término, justificados por la ratio de las distintas instituciones procesales en que dichos recortes o limitaciones se producen. Trasladada a la técnica de los suplicatorios, esta doctrina supone que «la denegación de los mismos haya de considerarse correcta, desde la perspectiva del art. 24.1 CE, únicamente en el caso de que dicha denegación sea conforme a la finalidad que la institución de la inmunidad parlamentaria persigue y en la que la posibilidad de denegación se fundamenta. Por el contrario, la respuesta negativa a la autorización para procesar será incorrecta y habrá un abuso de la figura constitucional de la inmunidad cuan-

\footnotetext{
106 STC 90/1985, de 22 de julio, FJ 5. ${ }^{\circ}$

107 Ibid., FJ 6. ${ }^{\circ}$, ab initio.

108 STC 7/1981, de 30 de marzo, FJ 6. ${ }^{\circ}$
} 
do ésta sea utilizada para fines que no le son propios» ${ }^{109}$. Con tal doctrina, indiscutiblemente, el Alto Tribunal afirma la necesidad constitucional de condicionar o sujetar a límites la facultad de las Cámaras de conceder o rechazar un suplicatorio, necesidad que se puede asimismo apreciar en otros ordenamientos análogos al nuestro.

La amenaza frente a la que se alza como garantía protectora la inmunidad, tal y como ya hemos expuesto, no es sino de naturaleza política, y consiste en la eventualidad de que se utilice la vía penal contra un parlamentario con la intención de perturbar el funcionamiento de la Cámara o de alterar su composición. A través de su pronunciamiento sobre el suplicatorio, a la Cámara le es dada la posibilidad de apreciar y evitar ese intento de manipulación. Ello exige, claro está, de una valoración, de un juicio de oportunidad o de intencionalidad, que ha de producirse de modo suficiente, esto es, en términos razonables o argumentales. Al principio jurisprudencialmente consagrado del «mayor valor» de los derechos fundamentales se anuda la doctrina constitucional en atención a la cual, cualquier acto por el que se coarta el libre ejercicio de un derecho constitucionalmente reconocido se considera de tal gravedad que necesita encontrar una especial causalización, por lo que el hecho o conjunto de hechos que lo justifican deben explicitarse con el fin de que los destinatarios conozcan las razones por las cuales su derecho se sacrificó y los intereses a los que se sacrificó. De este modo, como ha advertido el Tribunal ${ }^{110}$, «la motivación no es sólo una elemental cortesía, sino un riguroso requisito del acto de sacrificio de los derechos». En definitiva, el sacrificio del derecho no puede ser fruto de una decisión arbitraria, sino que ha de responder a una determinada finalidad que ha de asentarse en una justificación razonable.

No ha de extrañar tras todo lo expuesto que el Tribunal Constitucional haya subrayado especialmente la trascendencia de la valoración que ha de llevarse a cabo en sede parlamentaria. A su entender, «de la existencia o inexistencia de semejante juicio depende, en efecto, que el ejercicio de esa facultad potencialmente restrictiva del derecho a la tutela judicial se haya realizado conforme a su propia finalidad y depende, por consiguiente, en el supuesto de que la decisión parlamentaria sea contraria a permitir dicha tutela, que el derecho fundamental a ésta haya de considerarse o no vulnerado» ${ }^{111}$. De ahí que en su Sentencia 90/1985 el Tribunal, a la vista de

\footnotetext{
${ }^{109}$ STC 90/1985, de 22 de julio, FJ 6. ${ }^{\circ}$

110 STC 26/1981, de 17 de julio, FJ 13.

${ }^{111}$ Ibid., FJ 6. ${ }^{\circ}$, in fine.
} 
que un acuerdo del Pleno del Senado denegando la autorización para procesar a un senador aparecía desprovisto de motivación alguna, no siendo ésta tampoco aportada en las alegaciones que la representación de las Cortes Generales formulara ante el Tribunal, ni pudiendo tampoco ser suplida esa argumentación a partir de las circunstancias que concurrieron en la acción penal que dio lugar al suplicatorio, considerara violado el derecho fundamental reconocido en el art. 24.1 CE y declarara consecuentemente la nulidad de ese acuerdo parlamentario.

La inexcusabilidad de esta motivación o «juicio de oportunidad o de intencionalidad» del acto parlamentario denegatorio de un suplicatorio no quiere decir que cualquier fórmula de motivación tenga la virtualidad de despejar cualquier objeción a la constitucionalidad del acuerdo parlamentario. El Tribunal ha sido muy claro al efecto cuando aduce que «la fundamentación o motivación [...] no es ni puede ser garantía por sí misma, si no es en cuanto expresión de la coherencia del acuerdo parlamentario con la "finalidad" de la inmunidad, a la vista de las circunstancias del caso concreto»" ${ }^{112}$.

La exigencia de un «juicio de oportunidad» por parte de la Cámara tiene, pues, un sentido predominantemente material, esto es, no se trata tanto de que el acuerdo adopte una «forma motivada», cuanto de que exista en él, o quepa deducir del acto parlamentario, una motivación coherente con la finalidad de la prerrogativa parlamentaria. En coherencia con ello, en su Sentencia 206/1992 el Tribunal volvería a considerar vulnerado el derecho a la tutela efectiva de los jueces y tribunales de resultas de un Acuerdo del Pleno del Senado que denegó la autorización para procesar a un senador. Este Acuerdo parlamentario sí estaba motivado, pero en su valoración la Cámara omitió toda referencia a la posible incidencia de la concesión o no del suplicatorio en la composición de la Cámara o en su normal funcionamiento. A juicio del Tribunal ${ }^{113}$, «no hay nada en el mismo (en el Acuerdo del Senado) que pueda considerarse relevante para el sentido constitucionalmente perseguido a través de la prerrogativa de la inmunidad parlamentaria» ${ }^{114}$.

112 STC 206/1992, de 27 de noviembre, FJ 4. ${ }^{\circ}$

113 Ibid., FJ 5. ${ }^{\circ}$

114 Esta decisión no dejó, sin embargo, de suscitar una notable polémica. La sentencia fue acompañada de tres votos particulares, uno de ellos suscrito por dos magistrados. En el formulado por el señor Rodríguez Bereijo, al que se adheriría el señor González Campos, se sostendría que el Acuerdo del Pleno del Senado denegando el suplicatorio no era, en modo alguno, una decisión no ya carente de motivación, sino tampoco insuficientemente motivada para fundamentar la denegación del suplicatorio o de motivación no congruen- 


\section{El control en sede constitucional del acto parlamentario denegatorio del suplicatorio}

1. El Tribunal Constitucional, como «intérprete supremo de la Constitución», entre sus distintas funciones garantiza la conformidad a ésta de los actos parlamentarios mediante diversos instrumentos procesales. En el caso que nos ocupa, la Cámara que corresponda, con base en la facultad que le reconoce el art. 71.2 CE, lleva a cabo un acto o acuerdo singular sin fuerza de ley, del que, por todo lo hasta aquí expuesto, no puede excluirse la posibilidad de que incida, vulnerándolos, sobre derechos o libertades constitucionales que, según el art. 53.1 CE, vinculan a todos los poderes públicos, y para cuya protección, tratándose de derechos susceptibles de ella, el art. 53.2 posibilita acudir al recurso de amparo a fin de que el Tribunal examine las posibles vulneraciones de tales derechos fundamentales.

Por otro lado, no cabe olvidar que el constituyente estableció de modo expreso una doble delimitación respecto de la prerrogativa de la inmunidad: un límite material, que opera en relación a la detención de un diputa-

te con la finalidad de la inmunidad a la vista de las circunstancias del caso concreto. Tras ello, los disidentes formulaban una crítica a la sentencia de más amplio alcance: «En la Sentencia [...] — se afirma - se da un salto cualitativo de tal magnitud que contrasta llamativamente con la doctrina de este Tribunal desarrollada a propósito de la motivación de las sentencias y resoluciones de los órganos judiciales y deja tan reducido el margen de apreciación política a las Cámaras que, salvo hipótesis patológicas extremas de conflicto entre poderes difícilmente concebibles en un sistema democrático, puede hacer prácticamente imposible la denegación de la previa autorización para inculpar o procesar a un diputado o senador, y con ello ilusoria la institución misma de la inmunidad parlamentaria». En el voto particular suscrito por el magistrado señor Gimeno Sendra, éste significaría que su principal discrepancia con la sentencia se circunscribía a la doctrina reduccionista en ella sustentada. En fin, el magistrado señor García-Mon y González-Regueral, en su voto particular, manifestaría su creencia de que la sentencia jerarquizaba los preceptos constitucionales, considerando, de otro lado, que «una cosa es la necesidad de motivación que, naturalmente, ha de ser razonable, y otra muy distinta que solamente pueda ser una - el normal funcionamiento de las Cámaras - la que permita al órgano parlamentario denegar la autorización. Si esto fuera así de forma determinante, el constituyente podía y tenía que haberlo señalado en el art. 71.2 de la Constitución». En fin, dando un paso más en su crítica, este magistrado se manifiesta en absoluto desacuerdo con el paso adicional en la revisión de las decisiones parlamentarias que esta sentencia supone: «En el caso anterior (se refiere al caso resuelto por la STC 90/1985, ampliamente comentada) se constató la carencia de motivación, y aquí, como la motivación existe, se revisa la suficiencia o insuficiencia de las razones contenidas en el Acuerdo. La diferencia de inexistencia (sic) no exige más que su propia constatación, mientras que la suficiencia o insuficiencia de lo razonado entraña un juicio de valor o una ponderación que, en principio y salvo que se trate de una mera apariencia, equivale realmente a ejercer la facultad de otorgarla». 
do o senador, que es posible «en caso de flagrante delito», y otro de carácter temporal, puesto que el goce de la inmunidad tiene lugar «durante el periodo de su mandato».

En sintonía con lo que se acaba de exponer, es perfectamente posible revisar, desde la perspectiva constitucional, los actos parlamentarios de las dos Cámaras a través de los cuales éstas, en el libre ejercicio de la prerrogativa de la inmunidad, resuelven acerca de la solicitud de procesamiento o inculpación de alguno de sus miembros. El Tribunal Constitucional es lógicamente el órgano facultado al efecto, correspondiéndole tal facultad revisora cuando sea requerido para ello, por la vía y con los requisitos del recurso de amparo constitucional, mediante el examen del caso concreto. Tal criterio, obvio por lo demás, quedó establecido en la STC 90/1985 $5^{115}$, reiterándose, entre otras decisiones, en el Auto 1326/1988, en el que el Tribunal sostenía idéntica doctrina, pero formulada en términos negativos, con ánimo de delimitar hasta dónde alcanza su poder de revisión de estos actos. Una decisión parlamentaria referida a la prerrogativa de la inmunidad, se venía a decir, «no puede ser revisada por este Tribunal, salvo que se violen derechos fundamentales en esa decisión, como puede ser el derecho a la tutela judicial de terceros» ${ }^{116}$.

En cuanto a la que el propio Tribunal ha considerado como «delicada cuestión relativa a las posibilidades y límites de su jurisdicción de amparo frente a estas decisiones o actos parlamentarios», cabe decir, recordando ideas ya expuestas, que para el «intérprete supremo de la Constitución» el control que le corresponde acerca de la conformidad de las decisiones adoptadas en ejercicio de la inmunidad respecto al art. 24.1 de la Constitución «no puede llevarnos a revisar o a sustituir esa valoración (la realizada en sede parlamentaria), pero sí a constatar que el juicio de oportunidad o de intencionalidad se ha producido en las Cámaras, y ello de modo suficiente, esto es, en términos razonables o argumentales» ${ }^{117}$. Quiere ello decir que, como ya se ha puesto de relieve, la mera motivación del acuerdo parlamentario denegatorio de un suplicatorio no es suficiente para eximir el control en sede constitucional, que puede realizarse tanto en el supuesto de que el acuerdo se adopte en forma motivada —a lo que, según el Tribunal ${ }^{118}$, no se oponen la Constitución ni los Reglamentos de las Cámaras, pese a que éstos impongan carácter secreto a las deliberaciones previas a la

\footnotetext{
115 STC 90/1985, de 22 de julio, FJ 2. ${ }^{\circ}$

116 ATC 1326/1988, de 19 de diciembre, FJ 2. ${ }^{\circ}$, b).

117 SSTC 90/1985, de 22 de julio, FJ 6. ${ }^{\circ}$, y 206/1992, de 27 de noviembre, FJ 4. ${ }^{\circ}$

118 STC 90/1985, de 22 de julio, FJ 7. ${ }^{\circ}$, ab initio.
} 
aprobación de tales acuerdos- como en el supuesto de que dicha motivación no se aporte, aunque en tal supuesto el examen pueda revestir mayores dificultades.

Esta función de control jurisdiccional del Tribunal no ha dejado de suscitar controversias. Ello se hizo especialmente patente en la Sentencia 206/1992, de la que ya nos hemos ocupado con algún detenimiento, y dentro de ella, en los votos particulares que la acompañan.

En la controvertida decisión el Tribunal estimó ${ }^{119}$ que bastaba la simple lectura de la fundamentación jurídica del Acuerdo del Pleno del Senado por el que éste denegaba la autorización para procesar a un senador para apreciar su insuficiencia para fundamentar una denegación, constitucionalmente legítima, para procesar a un miembro de la Cámara. En su Acuerdo denegatorio de la autorización, el Senado puso especial énfasis en que las manifestaciones vertidas por el senador señor González Bedoya «lo fueron en el ejercicio de una función estrictamente política, más exactamente en el marco de una valoración política de la actividad de los órganos de gobierno de la Comunidad Autónoma de Cantabria, en el uso del libre ejercicio del derecho de crítica que corresponde a todo ciudadano, especialmente a quienes están investidos de la condición de representantes del pueblo español». El Tribunal se hará eco de cómo, aunque es bien evidente que las manifestaciones del senador se produjeron en un contexto político y en uso - correcto o no- de su libertad de expresión, «resulta claro que el instituto de la inmunidad no tiene como finalidad garantizar la libertad de expresión, ni aun cuando ésta viene ejercida por un representante del pueblo español». Por contra, la Cámara Alta omitió cualquier referencia a la incidencia que podría tener la concesión del suplicatorio sobre su composición o funcionamiento, ignorando con ello la verdadera finalidad del instituto de la inmunidad.

La decisión constitucional nos parece irreprochable. Ciertamente es restrictiva, pero ello creemos que casa a la perfección con la interpretación que se ha de dar a las prerrogativas parlamentarias, por muchas y muy variadas razones, como sería el caso de la perversa praxis que tradicionalmente se ha venido haciendo del instituto de la inmunidad. Como ha puesto de relieve la doctrina, la generosidad y arbitrariedad con que los Parlamentos han denegado sistemáticamente la mayoría de los suplicatorios ha convertido la prerrogativa de la inmunidad en un auténtico privilegio personal, que además es incapaz de cumplir ni siquiera las funciones consti-

119 STC 206/1992, de 27 de noviembre, FJ 5. ${ }^{\circ}$ 
tucionales que le servían de fundamento ${ }^{120}$. Otros autores han puesto de manifiesto la existencia de unos reflejos corporativos de los parlamentarios tendentes a crear mecanismos de autodefensa que parecen encontrar su mejor expresión en una institución tan eficaz en los inicios de la democracia como la de la inmunidad ${ }^{121}$. Y todo ello al margen ya de los argumentos de estirpe jurídica a los que aludimos al inicio de este trabajo para fundamentar la interpretación estricta de estas prerrogativas.

Si la doctrina reiterada del Tribunal ha fijado la razón de ser de la inmunidad en la preservación del funcionamiento de las Cámaras y en la salvaguarda de la composición que democráticamente les ha querido dar la voluntad soberana del pueblo, no se termina de comprender la discrepancia que en su voto particular expresa el magistrado señor Rodríguez Bereijo respecto a la que califica como afirmación rotunda y radical de la Sentencia 206/1992 de que «no hay nada en el mismo (el Acuerdo del Senado) que pueda considerarse relevante para el sentido constitucionalmente perseguido a través de la prerrogativa de la inmunidad parlamentaria». Y no lo hay, en efecto, porque para nada se alude en el Acuerdo parlamentario denegatorio del suplicatorio al fin último de la inmunidad, pues es una obviedad que este instituto no encuentra su razón de ser en la salvaguarda de la libertad de expresión de los parlamentarios. Si el criterio del carácter político del hecho, entendido de un modo laxo, bastara, la consecuencia a que ello conduciría sería, como bien dice Pizzorusso ${ }^{122}$, la constitución de un área de irresponsabilidad adicional respecto a lo previsto para las opiniones expresadas en el ejercicio de las funciones parlamentarias.

Y tampoco logramos captar el sustento de la crítica que formula en su voto particular el magistrado señor García-Mon y González-Regueral cuando viene a decir que la revisión de la suficiencia o insuficiencia de las razones contenidas en el Acuerdo del Senado «entraña un juicio de valor o una ponderación que, en principio y salvo que se trate de una mera apariencia, equivale realmente a ejercer la facultad de otorgarla $[s i c] \gg$. Entendemos que lo que el magistrado disidente quiere decir es que, al revisar la ponderación efectuada en sede parlamentaria, es el Tribunal quien realmente decide sobre el suplicatorio. No vemos motivo

120 A. FERnÁNDEZ-Miranda y CAMPOAMOR, «La inmunidad parlamentaria en la actualidad», Revista de Estudios Políticos, núm. 215, septiembre-octubre de 1977, pp. 207 y ss., en concreto p. 235.

121 P. FERnÁndez-Viagas Bartolomé, La inviolabilidad e inmunidad de los diputados y senadores. La crisis de los «privilegios» parlamentarios, Madrid, Civitas, 1990, p. 141.

122 A. Pizzorusso, «Las inmunidades parlamentarias...», op. cit., p. 45. 
de asombro en ello, pues, por poner un ejemplo, al hilo del recurso de amparo, es tarea habitual del Tribunal Constitucional revisar la ponderación de bienes o derechos llevada a cabo por los jueces ordinarios, sustituyendo en muchas ocasiones la ponderación judicial por la suya propia. Si a las Cámaras les bastara con motivar el acuerdo parlamentario de denegación de un suplicatorio, tal requisito se convertiría en un puro formalismo carente de toda sustancia, y con ello en caldo de cultivo para una utilización abusiva del instituto.

2. Constatada por el Tribunal Constitucional la violación del derecho fundamental a la tutela judicial por el acto de una Cámara denegatorio del suplicatorio para el procesamiento de uno de sus miembros, la consecuencia que a ello se anuda es la declaración de nulidad del acuerdo parlamentario, que se extiende, en cuanto a sus efectos, a todos los actos posteriores que sean consecuencia del mismo. El reconocimiento del derecho del recurrente a que la autorización para procesar al parlamentario no sea denegada por razones ajenas a la finalidad de la institución de la inmunidad puede exigir, según el caso y con vistas a su pleno restablecimiento, de un nuevo acuerdo de la Cámara ${ }^{123}$. En otras ocasiones, el Tribunal ha declarado la nulidad de Autos dictados por la Sala Segunda del Tribunal Supremo, decretando el sobreseimiento libre de actuaciones respecto de un parlamentario, al estar basados en un Acuerdo parlamentario denegatorio del suplicatorio declarado nulo por otra decisión anterior del juez constitucional ${ }^{124}$. En cualquier caso, la nulidad de los Autos de libre sobreseimiento dictados por la Sala de lo Penal del Tribunal Supremo al amparo de un previo acuerdo de una Cámara denegatorio de la autorización para procesar a uno de sus miembros presupone que se retrotraigan las actuaciones al momento inmediatamente anterior a la resolución de la mencionada Sala por la que, en forma de suplicatorio, se solicita de la Cámara la autorización prevista en el art. 71.2 CE ${ }^{125}$, lo que viene a entrañar obviamente un nuevo pronunciamiento de la mencionada Cámara en torno al suplicatorio.

3. Los problemas que suscita la prerrogativa de la inmunidad, los aspectos contradictorios de la misma, hacen harto difícil, como reconoce con una perspectiva general Pizzorusso ${ }^{126}$, reconducirla a esquemas coherentes y racionales, resultando en ocasiones todavía más desconcertante el

123 Así se decidió en la STC 90/1985, de 22 de julio.

124 Así se decidió en la STC 125/1988, de 24 de junio.

${ }^{125}$ Así se decidió en la STC 206/1992, de 27 de noviembre.

126 A. Pizzorusso, «Las inmunidades parlamentarias...», op. cit., p. 46. 
examen de su praxis. No en vano una amplia doctrina, particularmente en Italia, se ha mostrado notablemente crítica respecto de esta garantía, calificándola de institución anacrónica, obsoleta y contraria a los principios fundamentales del moderno Estado constitucional ${ }^{127}$.

En el marco de un Estado que asegura el imperio de la ley como expresión de la voluntad popular y la sujeción de todos a ella, una institución como la de la inmunidad, concebida y aplicada de un modo acorde a los valores superiores de nuestro ordenamiento, difícilmente tiene otra razón de ser que la que estrictamente le ha dado en su, a nuestro juicio, acertada jurisprudencia el Tribunal Constitucional. En la misma dirección, Fernández-Viagas, quien fuera miembro de ese órgano, pudo señalar hace una veintena de años ${ }^{128}$ que las Cámaras, al decidir sobre la concesión o no de un suplicatorio, sólo deberían tener en cuenta las repercusiones que la acción penal pudiera comportar sobre su composición política. Se trataría, pues, de determinar si la presencia de un parlamentario es imprescindible para mantener la composición ideológica de la Asamblea, resultando indispensable mantenerle en la Cámara en orden al respeto de las reglas del juego democrático. Pareciéndonos ello acertado, tan sólo añadiríamos que, como es obvio, las Cámaras deberán asimismo atender a las circunstancias propias del caso.

Un entendimiento así de la institución, que es justamente el que ha hecho suyo nuestro Tribunal Constitucional, puede, desde luego, conducir a privar de gran parte de su operatividad a la garantía de la inmunidad, pero ésta en modo alguno nos parece razón suficiente como para neutralizar la anterior comprensión del instituto. Esta concepción restrictiva de la inmunidad no vacía por entero de contenido a la institución. Reduce su operatividad, ciertamente, pero en el marco de un Estado democrático de Derecho, una institución nacida en tiempos pretéritos y en circunstancias harto alejadas de las de hoy, y que pugna con principios nucleares de ese Estado, no puede ser objeto de otra interpretación que la que la restrinja estrictamente a su última ratio.

127 Éste es el caso, entre otros, de C. MorTatr, Istituzioni di Diritto pubblico, 9. a ed., Padova, CEDAM, 1975, pp. 494-495. En similares términos se pronuncia T. MARTINES, Diritto

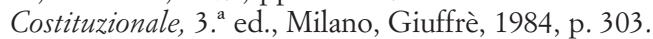

128 Cfr. al respecto P. Fernández-Viagas Bartolomé, La inviolabilidad e inmunidad de los diputados y senadores..., op. cit., pp. 142 y ss. 


\section{EL AFORAMIENTO DE LOS PARLAMENTARIOS}

1. $\mathrm{El}$ art. 71.3 CE establece el que se conoce como privilegio de fuero o también como prerrogativa de aforamiento especial, por virtud de la cual la competencia para conocer de las causas contra diputados y senadores se otorga tan sólo a la Sala de lo Penal del Tribunal Supremo. Junto a la inviolabilidad e inmunidad, aunque creemos que con menor trascendencia que ellas, conforma la tríada de prerrogativas de interés en el tema que nos ocupa. Como ha entendido el Alto Tribunal ${ }^{129}$, esta prerrogativa, que teleológicamente, y en sede estrictamente procesal, opera como complemento y cierre - aunque con su propia y específica autonomía - de las de la inviolabilidad y la inmunidad, se orienta hacia los mismos objetivos comunes que las hasta ahora analizadas.

En el pasado, esta garantía, en algunos países, se conformó como el derecho de ciertos parlamentarios a ser juzgados por la propia Asamblea a la que pertenecían. Así, en Inglaterra, hasta su abolición por la Criminal Justice Act de 1948, los lores gozaban del privilegio de ser juzgados por sus propios pares.

La precisa finalidad cuya salvaguarda se persigue mediante la constitucionalización de la prerrogativa de aforamiento especial de diputados y senadores es la de proteger la propia independencia y sosiego, tanto del órgano legislativo como del jurisdiccional, frente a potenciales presiones externas o las que pudiese ejercer el propio encausado por razón del cargo político e institucional que desempeña. De este modo, la prerrogativa de aforamiento actúa como «instrumento para la salvaguarda de la independencia institucional tanto de las Cortes Generales como del propio Poder Judicial, o, dicho de otro modo, el aforamiento preserva un cierto equilibrio entre los poderes y, al propio tiempo, la resistencia más eficaz frente a la eventual trascendencia de la resolución judicial en la composición del Parlamento». Por ello, no es extraño que el constituyente atribuyese de modo expreso el conocimiento de tales causas a la Sala de lo Penal del Tribunal Supremo, en tanto que órgano jurisdiccional superior de los que integran aquel poder del Estado.

El aforamiento entronca con el derecho al juez ordinario predeterminado por la ley, en tanto que esta prerrogativa va dirigida a determinar el órgano judicial competente para el conocimiento de las causas seguidas

129 STC 22/1997, de 11 de febrero, FJ 6. ${ }^{\circ}$ 
contra diputados y senadores. La predeterminación legal —recordémoslo- significa que la ley, con generalidad y anterioridad al caso, ha de contener los criterios de determinación competencial cuya aplicación a cada supuesto litigioso permita determinar cuál es el Juzgado o Tribunal llamado a conocer del caso. De esta forma, la Sala Segunda del Tribunal Supremo es, respecto de las acciones penales dirigidas contra diputados y senadores, «el juez ordinario predeterminado por la ley», esto es, aquél constituido con arreglo a las normas procesales de competencia preestablecidas, en este caso, por la propia Constitución en su art. 71.3. Puede hablarse, pues, de la predeterminación constitucional (en vez de legal) del órgano jurisdiccional competente que comporta el seguimiento de una distinta tramitación procesal de las causas contra diputados y senadores, que, como ha reconocido el Tribunal Constitucional ${ }^{130}$, no se configura con ventajas especiales, ya que en este proceso es viable, excepcionalmente, la inexistencia de un segundo grado jurisdiccional. La diferenciación de este proceso viene exigida por ese interés superior del ordenamiento que es la independencia y el prestigio de las instituciones, imprescindible en el funcionamiento de todo Estado democrático.

En su Sentencia 51/1985, el Tribunal tuvo oportunidad de pronunciarse sobre este importante aspecto de las garantías del debido proceso legal que es la exigencia de un segundo grado jurisdiccional respecto de las causas penales referentes a parlamentarios ${ }^{131}$. El derecho a la tutela judicial efectiva y a un proceso con todas las garantías no supone por sí solo el derecho a una doble instancia jurisdiccional, que no se halla expresamente reconocido en el art. 24 de la Norma suprema. Sin embargo, en cuanto que el art. 10.2 del Texto fundamental establece que «las normas relativas a los derechos fundamentales y a las libertades que la Constitución reconoce se interpretarán de conformidad con la Declaración Universal de Derechos Humanos y los tratados y acuerdos internacionales sobre las mismas materias ratificados por España», parece claro, a la vista del art. 14, núm. 5, del Pacto Internacional de Derechos Civiles y Políticos ratificado por España, que el derecho al doble grado de jurisdicción en materia penal es una de las garantías a que la Constitución se refiere al emplear la cláusula «todas» en esa alusión del art. 24.2 a «un proceso público [...] con todas las garantías». Así lo vino a reconocer el Tribunal en su Sentencia 42/1982 ${ }^{132}$. Sin

130 Ibid.

${ }^{131}$ Cfr. al respecto STC 51/1985, de 10 de abril, FJ 3. ${ }^{\circ}$

132 STC 42/1982, de 5 de julio, FJ 3..$^{\circ}$ Recuerda el Tribunal en esta Sentencia que el art. 14.5 del Pacto consagra el derecho de toda persona declarada culpable de un delito a 
embargo, el precepto del Pacto Internacional, aun siendo Derecho interno, no es bastante para crear per se recursos inexistentes. $Y$ en el supuesto en cuestión sucede que contra la sentencia pronunciada por el Tribunal Supremo no cabe recurso de casación «por prohibirlo explícitamente el art. 847 de la Ley de Enjuiciamiento Criminal». Por lo demás, la especial protección de que gozan, ex Constitutione, en este caso los senadores y diputados en atención a su cargo contrarresta en cierto modo la imposibilidad de acudir a una instancia superior, pudiendo afirmarse, según el Tribunal, «que esas particulares garantías que acompañan a senadores y diputados disculpan la falta de un segundo grado jurisdiccional, por ellas mismas y porque el órgano encargado de conocer en las causas en que puedan hallarse implicados es el superior en la vía judicial ordinaria».

En armonía con lo que se acaba de exponer, el Alto Tribunal ha admitido ${ }^{133}$ que, si bien esta garantía parlamentaria, al igual que las otras dos que se proclaman en el art. $71 \mathrm{CE}$, puede ser reivindicada a través del proceso de amparo en cuanto se incorpora sin mayor dificultad al contenido del derecho fundamental reconocido en el art. 23.2 CE (derecho de acceso a los cargos públicos), el carácter específico del aforamiento entronca más directamente con el derecho al juez ordinario predeterminado por la ley que contempla el art. 24.2 CE, de modo que el instituto del aforamiento especial, dada su propia y específica autonomía, encuentra su acomodo natural también en el mencionado art. 24.2 de la Norma suprema.

2. El art. 71.3 CE no establece ninguna limitación específica en relación con el aforamiento de los miembros de las Cortes Generales; sin embargo, en sintonía con el criterio general de interpretación estricta al que hay que atender respecto de las prerrogativas parlamentarias, es indudable que su interpretación no puede realizarse en términos absolutos y con desconocimiento de la finalidad a la que constitucionalmente sirve. Ello tiene su importancia respecto a la delimitación del alcance temporal de esta prerrogativa. El aforamiento de los parlamentarios y, en particular, su alcance temporal — ha dicho el Tribunal — ${ }^{134}$, no puede interpretarse al

que el fallo condenatorio y la pena que se le haya impuesto sean sometidos a un Tribunal superior, conforme a lo prescrito por la ley. Este mandato, incorporado a nuestro Derecho interno, no es bastante para crear por sí mismo recursos inexistentes, pero obliga a considerar que entre las garantías del proceso penal a las que genéricamente se refiere la Constitución en su art. 24.2 se encuentra la del recurso ante un Tribunal superior.

133 Entre otras, en las SSTC 22/1997, de 11 de febrero, FJ 2. ${ }^{\circ}$, y 68/2001, de 17 de marzo, FJ 2. $\left..^{\circ}, \mathrm{b}\right)$.

${ }^{134}$ STC 22/1997, de 11 de febrero, FJ 7. ${ }^{\circ}$ 
margen de los efectos que se vinculan a la prerrogativa de la inmunidad y la concesión, en su caso, del oportuno suplicatorio.

La cuestión del alcance temporal del aforamiento especial de los parlamentarios se planteó con ocasión de una demanda de amparo suscitada, en síntesis, al hilo de los siguientes hechos: tras haber sido nombrado diputado, se instruyeron contra el demandante de amparo diligencias previas por la presunta comisión de un delito de desobediencia en el desempeño de sus funciones como alcalde de Andújar. Manifestada su condición de aforado, la causa fue remitida a la Sala Segunda del Tribunal Supremo, que declaró su competencia jurisdiccional para conocer del asunto. Tras la instrucción, la Sala estimó que existían indicios racionales de culpabilidad, solicitando del Congreso de los Diputados la concesión del oportuno suplicatorio para procesar, que la Cámara concedió. Acordándose la apertura definitiva de la causa, se constató que el encausado había perdido su condición de miembro de las Cortes Generales, dictando la Sala Segunda un auto por el que declinaba el conocimiento de los hechos, remitiendo las actuaciones al Juzgado de Instrucción de Andújar. Contra ese auto - que devino firme al desestimarse, por otro auto posterior, el recurso de súplica promovido por el recurrente- se interpuso recurso de amparo, al considerarse que tal interpretación restrictiva de la prerrogativa de aforamiento contrariaba el art. $71 \mathrm{CE}$, vulnerando al unísono el derecho del solicitante de amparo a una tutela judicial efectiva y a un proceso sin dilaciones indebidas.

En su Sentencia razona el Tribunal Constitucional al respecto ${ }^{135}$ que, iniciada la causa contra un diputado o senador, y si éste, de forma sobrevenida, hubiese perdido su condición de aforado, la interpretación de la legalidad procesal aplicable a los efectos de determinar si la Sala de lo Penal del Tribunal Supremo debe mantener su competencia continuando con el enjuiciamiento de la causa, o si, por el contrario, debe declinarla defiriendo la causa al Juzgado de Instrucción competente locus commissi delicti, es una cuestión de legalidad que incide, sin embargo, en el contenido de un precepto constitucional, el art. $71.3 \mathrm{CE}$, y en la prerrogativa de aforamiento especial en él establecida, así como en el derecho fundamental al juez ordinario predeterminado por la ley.

El problema de la perpetuatio iurisdictionis debe ser abordado a la luz de la doctrina sobre las prerrogativas parlamentarias sentada por el Tribunal, y de la que nos hemos hecho eco en diversas ocasiones, de forma tal

135 STC 22/1997, de 11 de febrero, FJ 7. 
que la observancia del instituto procesal se cohoneste con la finalidad a la que sirve esta prerrogativa, pues lo contrario supondría una extensión del ámbito temporal de la prerrogativa, innecesaria para salvaguardar su finalidad, lo que la convertiría en un mero privilegio personal.

A partir de estas premisas, el Tribunal Constitucional iba a entender ${ }^{136}$ que, constatada por la Sala Segunda del Tribunal Supremo la pérdida sobrevenida de la condición de parlamentario de que gozaba el demandante de amparo al tiempo de iniciarse la acción penal, la devolución de la causa al Juzgado de Instrucción no supuso vulneración alguna del derecho fundamental a la tutela judicial efectiva y al juez predeterminado por la ley, toda vez que la cognición del Tribunal Supremo en este tipo de procesos sólo se justifica constitucionalmente por razón de la prerrogativa de aforamiento y en atención a la función institucional que le es propia, y no cuando (como en el caso acontece) ésta queda privada de su razón de ser por haber perdido el encausado su condición de miembro de las Cortes Generales. Lo contrario supondría una extensión del ámbito temporal de la prerrogativa, que la convertiría en un privilegio personal, que a su vez redundaría en una desproporcionada e innecesaria alteración del régimen común del proceso penal.

En resumen, el Tribunal iba a establecer la doctrina de que esta prerrogativa, al igual que las restantes que conforman el estatuto del parlamentario, ha de ser objeto de una interpretación estricta en atención al interés que preserva, interés que decae cuando se pierde la condición de parlamentario y no cabe temer que el juzgador se sienta cohibido por el peso institucional de la representación popular o abrumado por la trascendencia de su decisión en la composición de la Cámara.

De esta forma, el «intérprete supremo de la Constitución» convalidaba la interpretación de la legalidad ordinaria llevada a cabo por la Sala Segunda del Tribunal Supremo, que, en una interpretación restrictiva de la prerrogativa de aforamiento basada en primar teleológicamente su dimensión funcional y objetiva respecto de la vertiente meramente personal y subjetiva, entendió que, fuera del periodo de su mandato, la competencia de la Sala Segunda del Tribunal Supremo sólo se extiende a los diputados y senadores electos o al supuesto en que, finalizado su mandato, estando concedida y vigente la autorización de la Cámara para proceder contra uno de sus miembros, los hechos cometidos estuvieran directamente relacionados con el ejercicio de la función pública inherente al cargo representati-

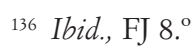


vo. El Tribunal Constitucional admite que esta interpretación de la Sala de lo Penal del Supremo no se ajusta al tenor literal de la Ley de 9 de febrero de 1912, que es la que rige la cuestión, pero precisa que, «tratándose de una norma preconstitucional, nada impide al Tribunal Supremo modularla a las circunstancias del caso, deduciendo de la Constitución y de las normas procesales la pauta interpretativa a seguir».

En definitiva, para el Alto Tribunal, cuando la Constitución proclama en su art. 71.3 la competencia de la Sala de lo Penal del Tribunal Supremo en las causas contra diputados y senadores está estableciendo un contenido absolutamente indisponible de esta prerrogativa, que se traduce en que, «cualquiera que sea la causa, ésta pasará al Tribunal Supremo desde el momento en que la misma afecte a un diputado o senador, y mientras no pierda la condición de miembro de las Cortes Generales». Pero, más allá de este contenido indisponible, el juez de la legislación admite que las leyes procesales o el propio Tribunal Supremo, en su función de intérprete de la preconstitucional Ley de 1912, pueden resolver de distinta manera acerca de la perpetuatio iurisdictionis.

La sentencia no fue pacífica, pues a ella se unió un voto particular suscrito por dos magistrados que mostraron su discrepancia con la decisión de la mayoría no sólo por contravenir el tenor del inciso segundo del art. 7 de la Ley de 9 de febrero de 1912 («si la autorización — de la Cámara-fuese concedida, continuará el procedimiento hasta que recaiga resolución o sentencia firme, aun cuando antes de dictarla fueren disueltas las Cortes a que perteneciere el senador o diputado objeto del suplicatorio»), sino también por infringir, a juicio de los disidentes, el art. $71.3 \mathrm{CE}$ que, a diferencia de sus párrafos anteriores, no somete el aforamiento a los mismos requisitos, material y temporal, que la inviolabilidad e inmunidad parlamentarias.

En el voto particular se aludía, al margen ya de las razones teóricas, a la praxis judicial, que en aquel momento revelaba que sólo durante el año 1996 un total de 102 causas se habían seguido frente a aforados (dato, como es obvio, que no atendía sólo a los parlamentarios), a lo que se añadía el previsible sustancial aumento de la competencia objetiva de la Sala de lo Penal del Tribunal Supremo derivado de la vigencia y aplicación del nuevo Código Penal de 1995 (aprobado mediante la Ley Orgánica 10/1995, de 23 de noviembre, y cuya entrada en vigor se fijaba a los seis meses de su completa publicación en el Boletín Oficial del Estado), circunstancias que permitían inferir razonablemente, según los disidentes, la posibilidad de que se produjeran ciertos retrasos o dilaciones procesales, «con 
el consiguiente riesgo de que la prerrogativa del aforamiento de los miembros de las Cámaras legislativas garantizada por el art. 71.3 CE quede vacía de contenido» ${ }^{137}$.

Quizá convenga decir, ante las críticas de índole legal y constitucional aducidas frente a la sentencia por los discrepantes, que el argumento atinente a las previsiones de la Ley de 1912 ha de ser relativizado, y no ya por la antigüedad del texto legal, sino por la conveniencia de interpretarlo de modo acorde con la Constitución. Y en cuanto al razonamiento de que el art. 71.3 CE no sujeta el aforamiento a requisito alguno, siendo cierto, no se puede perder de vista la estrecha conexión que debe existir entre las prerrogativas de la inmunidad y del aforamiento, siendo bien significativa la delimitación temporal que el art. 71.2 CE establece respecto de la inmunidad, circunscribiéndola al periodo de mandato de diputados y senadores. En cualquier caso, estos argumentos críticos no hacen sino poner de manifiesto la inexcusabilidad de una nueva regulación procesal de la materia.

3. Una última cuestión, ya referida al hablar de la inmunidad por su íntima conexión con ella, es la del momento preciso en el que la instrucción de la causa ha de elevarse a la Sala de lo Penal del Tribunal Supremo por poder resultar implicado en la misma un miembro de las Cortes Generales. Como ya expusimos, el art. 2 de la Ley de 9 de febrero de 1912 hace una genérica referencia a la aparición «de indicios de responsabilidad contra algún senador o diputado». La Sala de lo Penal del Supremo, en su función de intérprete de esa ley preconstitucional, viene entendiendo que no basta para la operatividad de la prerrogativa de aforamiento del art. 71.3 CE la mera imputación personal, sin datos o circunstancias que la corroboren, a un aforado, requiriéndose la existencia de indicios fundados de responsabilidad contra él, dado que los aforamientos procesales constituyen normas procesales de carácter excepcional que, por tal circunstancia, deben ser interpretadas y aplicadas restrictivamente. Esta doctrina, que en definitiva exige que «existan indicios o sospechas fundados con una mínima verosimilitud o solidez sobre la participación de un diputado o senador en los hechos objeto de investigación penal para que entre en juego la garantía de aforamiento especial prevista en el art. $71.3 \mathrm{CE} \gg^{138}$, ha sido en varias ocasiones convalidada por el «intérprete supremo de la Constitu-

137 STC 22/1997, de 11 de febrero. Voto particular que formulan conjuntamente los magistrados señores don Vicente Gimeno Sendra y don Pablo García Manzano, punto 5.

138 STC 68/2001, de 17 de marzo, FJ 2. ${ }^{\circ}$, c). 
ción», para el que la misma en modo alguno puede ser calificada de irrazonable o arbitraria, ni tildada de contraria a la finalidad a la que sirve la garantía de aforamiento.

4. Debemos hacernos eco, muy brevemente, de una última cuestión: el régimen de la prerrogativa de aforamiento de los miembros de los Parlamentos o Asambleas Legislativas autonómicas, que aunque no se halle contemplado por la Constitución, sí está previsto por los respectivos Estatutos de Autonomía. Éstos han previsto la tríada de prerrogativas que hemos examinado, bien que, en relación a la inmunidad, han omitido toda referencia a la inexcusable autorización parlamentaria para la inculpación o procesamiento de un miembro de la Cámara autonómica. Puede decirse, pues, que la inmunidad de los parlamentarios autonómicos no opera más que en el primero de los dos sentidos que prevé el art. 71.2 de la Constitución, o lo que es igual, en el de exención de cualquier posible detención de un parlamentario en ejercicio de su mandato, con la sola salvedad del supuesto de delito flagrante.

En cuanto a la prerrogativa de aforamiento, la regla estatutaria más común es la de que corresponde al Tribunal Superior de Justicia de la Comunidad Autónoma decidir sobre la inculpación, prisión, procesamiento y juicio de un parlamentario autonómico por los actos delictivos cometidos en el ámbito territorial de la Comunidad Autónoma, siendo exigible la responsabilidad penal ante la Sala de lo Penal del Tribunal Supremo por aquellos actos delictivos cometidos fuera del mencionado ámbito territorial, fórmula dispositiva que ha venido rigiendo en todos los Estatutos de Autonomía y que, en síntesis, presupone supeditar el procesamiento no a la autorización dada en sede parlamentaria, sino a la decisión del correspondiente Tribunal Superior de Justicia ${ }^{139}$.

139 El nuevo Estatuto de Autonomía de Cataluña, aprobado por la Ley Orgánica 6/2006, de 19 de julio, altera parcialmente la fórmula estatutaria tradicional en relación a las prerrogativas parlamentarias, asimilándola en alguna medida, aunque no en su totalidad, a la del art. 71 CE. La diferencia sustancial sigue consistiendo en que no se otorga al Parlamento de Cataluña la facultad de autorizar el procesamiento de uno de sus miembros. O dicho de otro modo, la autorización parlamentaria no se contempla como requisito procesal para la inculpación o procesamiento de un miembro del Parlamento catalán. A tenor de los dos primeros apartados del art. 57 del nuevo Estatuto de Autonomía:

«1. Los miembros del Parlamento son inviolables por los votos y las opiniones que emitan en el ejercicio de su cargo. Durante su mandato tendrán inmunidad a los efectos concretos de no poder ser detenidos salvo en caso de flagrante delito.

2. En las causas contra los diputados es competente el Tribunal Superior de Justicia de Cataluña. Fuera del territorio de Cataluña la responsabilidad penal es exigible en los mismos términos ante la Sala de lo Penal del Tribunal Supremo». 


\section{REFLEXIÓN FINAL}

La materia referente a las prerrogativas parlamentarias, como se ha visto, carece de una legislación posconstitucional de desarrollo, siendo, todavía hoy, una ley ya centenaria (del año 1912) la específica norma legal a la que es necesario acudir. Ello está en la base de la inseguridad jurídica que comporta la situación legal existente en torno a estas prerrogativas, que ha sido puesta de relieve por el Tribunal Constitucional en diversas decisiones, instando, bien que sin éxito hasta hoy, al legislador a actuar. Por lo demás, el Tribunal Constitucional, ciertamente, ha llevado a cabo una decisiva labor de racionalización, que, de decidirse el legislador a afrontar su tarea de normación, le facilitaría en gran medida su obra legislativa.

Por otro lado, el Alto Tribunal, con una interpretación de estas prerrogativas presidida por un criterio esencialmente teleológico y, en perfecta sintonía con ello, asentada en su visión restrictiva, ha hecho posible, a nuestro entender, su acomodo a las exigencias propias de un Estado constitucional de nuestro tiempo, en el que valores tan extraordinariamente relevantes como los de justicia e igualdad, o derechos fundamentales tan decisivos en el Estado de Derecho como el derecho a la tutela judicial efectiva, no pueden sin más ceder en beneficio de instituciones arcaicas, propias de épocas pasadas, que aún hoy tienen el rancio sabor de los privilegios, y cuya pervivencia constitucional debe inexcusablemente armonizarse con aquellos valores y derechos, lo que no es posible salvo que, como ha hecho el Tribunal, estas prerrogativas sean entendidas de modo harto estricto y con una visión inequívocamente institucional de las mismas. 